\author{
ANDRZEJ ARAŹNY ${ }^{1,2}$, MAREK KEJNA ${ }^{1}$, TOMASZ WAWRZYNiAK ${ }^{3}$, MARZENA OSUCH ${ }^{3}$,
} JOANNA PLENZLER ${ }^{4}$, TOMASZ BUDZIK ${ }^{5}$

${ }^{1}$ Katedra Meteorologii i Klimatologii

Wydziat Nauk o Ziemi i Gospodarki Przestrzennej

Uniwersytet Mikołaja Kopernika w Toruniu

Lwowska 1, 87-100 Torun

${ }^{2}$ Centrum Badan Zmian Klimatu

Lwowska 1, 87-100 Torun

${ }^{3}$ Instytut Geofizyki PAN

Księcia Janusza 64, 01-452 Warszawa

${ }^{4}$ Zakład Biologii Antarktyki

Instytut Biochemii i Biofizyki PAN

Pawińskiego 5a, 02-106 Warszawa

${ }^{5}$ Katedra Klimatologii

Wydział Nauk o Ziemi

Uniwersytet Ślaski w Katowicach

Bedzinska 60, 41-200 Sosnowiec

E-mail: andy@umk.pl

\title{
ZMIANY KLIMATU W EKOSYSTEMACH ARKTYKI I ANTARKTYKI
}

\section{WSTEP}

W ostatnich dekadach obserwujemy gwałtowne ocieplenie na kuli ziemskiej. W latach 2011-2020 średnia temperatura powietrza była o $1,09^{\circ} \mathrm{C}$ wyższa od tej $z$ lat 1850-1900. Według Raportu IPCC (2021) prognozuje się, że w latach 2021-2040 temperatura powietrza wzrośnie o ok. $1,0-5,7^{\circ} \mathrm{C}$ (w zależności od skali emisji gazów cieplarnianych). Przyczyna ocieplenia jest rosnaca koncentracja gazów cieplarnianych, która redukuje wypromieniowanie długofalowe ciepła w przestrzeń kosmiczną. W konsekwencji Ziemia otrzymuje więcej energii przychodzacej od Słońca w stosunku do energii emitowanej w przestrzeń kosmiczna (IPCC 2021).

Największe zmiany klimatyczne obserwowane sa w regionach polarnych, w Arktyce i Antarktyce (Ryc. 1). W ciagu ostatniej dekady Arktyka ociepliła się o $0,75^{\circ} \mathrm{C}$, znacznie przewyższając trend światowy, podczas gdy temperatura powietrza na Antarktydzie charakteryzowała się stabilnościa, $z$ wyjąt- kiem rejonu Półwyspu Antarktycznego. Gdy temperatura Ziemi wzrośnie o $2^{\circ} \mathrm{C}$, średnia roczna temperatura w Arktyce i Antarktyce może osiagnąć wyższe wartości, odpowiednio ok. $4^{\circ} \mathrm{C}$ i $2^{\circ} \mathrm{C}$, a zima $7^{\circ} \mathrm{C}$ i $3^{\circ} \mathrm{C}$ (Post i współaut. 2019). W Arktyce ocieplenie klimatu jest wzmacniane przez tzw. Arctic amplification (PREVIDI i współaut. 2021). Obserwowane zmiany klimatu $\mathrm{w}$ regionach polarnych wpływaja na ekosystemy ladowe i morskie. Spodziewane konsekwencje wzmożonego ocieplenia Arktyki i Antarktyki obejmuja m.in. redukcję grubości i powierzchni lądolodów kontynentalnych, zmniejszenie powierzchni lodowców górskich, ubytek powierzchni lodów morskich oraz wieloletniej zmarzliny i pokrywy śnieżnej. W wyniku deglacjacji zmienia się linia brzegowa i przybrzeżna obszarów lądowych. Szybko zachodza zmiany $\mathrm{w}$ faunie $\mathrm{i}$ florze, m.in. na tereny polarne wkracza roślinność krzewiasta. Ocieplenie regionów polarnych powoduje również polepszenie odczuwalnych warunków pogodowych dla człowieka. 


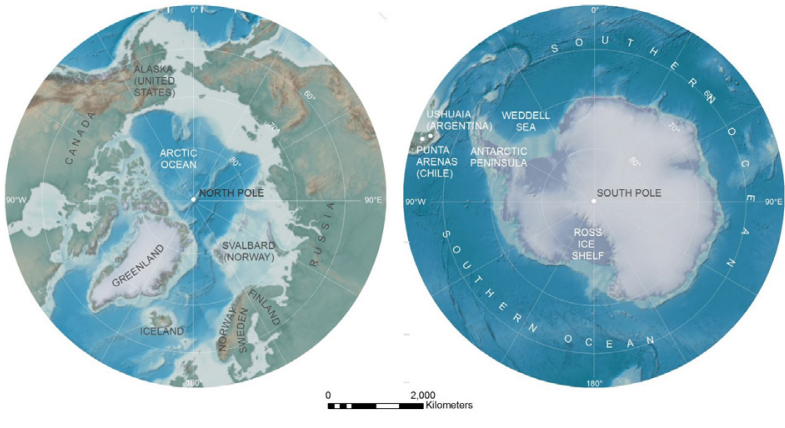

Ryc. 1. Mapa Arktyki i Antarktyki (WMO 2017).

Celem niniejszej pracy jest przedstawienie aktualnego stanu wiedzy na temat zmian klimatu w Arktyce i Antarktyce, głównie na podstawie temperatury powietrza i opadów atmosferycznych. Szczegółowo omówiono zmiany klimatu $\mathrm{w}$ obu obszarach polarnych, gdzie od lat 70 . XX w. działaja całoroczne polskie stacje polarne: w Arktyce na południowym Spitsbergenie Stacja im. Stanisława Siedleckiego w Hornsundzie oraz w Antarktyce na Wyspie Króla Jerzego Stacja im. Henryka Arctowskiego. W pracy przedstawiono również wpływ zamian klimatu na ekosystemy obszarów polarnych.

\section{ZMIANY KLIMATU W ARKTYCE}

Temperatura powietrza jest jednym $z$ głównych indykatorów zmian klimatu. Badania zmian temperatury $\mathrm{w}$ Arktyce $\mathrm{w}$ ostatnich 100 latach były przedmiotem prac wielu autorów (PRZYBYLAK 2002, 2007b, 2016; BOBYLEV i współaut. 2003; MCBEAN i współ-

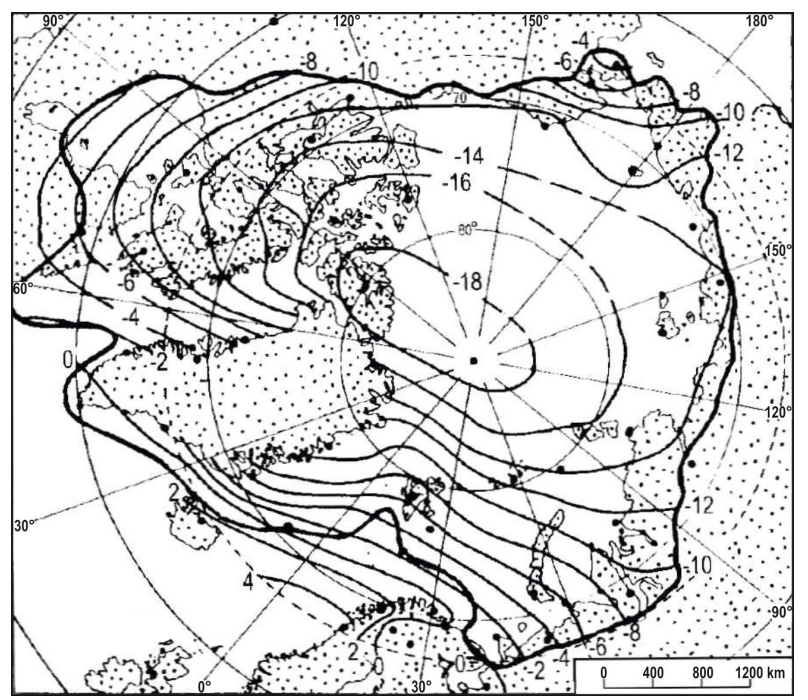

Ryc. 2. Rozkład przestrzenny średniej rocznej temperatury powietrza w Arktyce w latach 19511990 (PRZYBYLAK 2016).

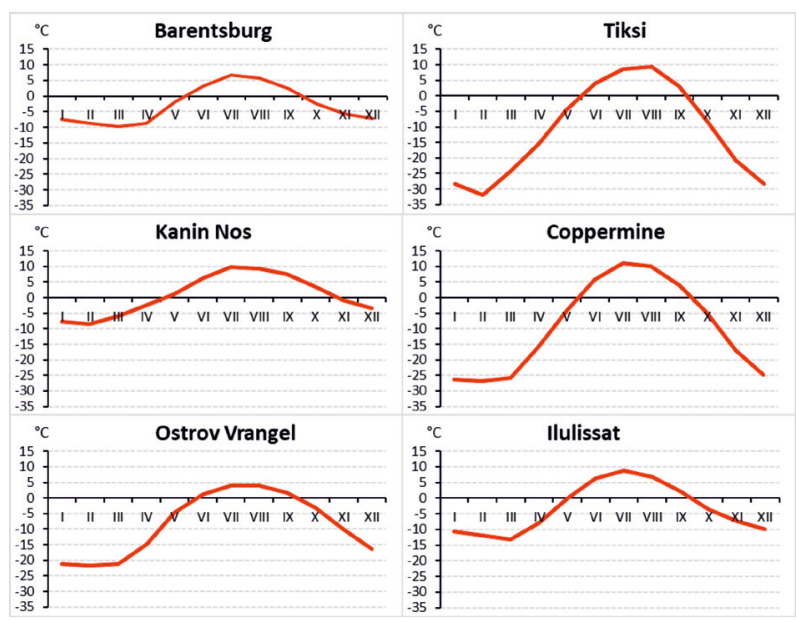

Ryc. 3. Przebieg roczny temperatury powietrza na wybranych stacjach arktycznych w latach 20072016.

aut. 2005; TURNER i MARSHALL 2011; PRZYBYLAK i WYSZYŃSKI 2020).

W Arktyce występuje klimat polarny $z$ podtypem morskim i kontynentalnym. Klimat morski jest charakterystyczny dla Islandii, Spitsbergenu, norweskiego wybrzeża i przyległych części Rosji. Natomiast klimat kontynentalny występuje na Grenlandii, w Skandynawii, na Syberii, Alasce i kanadyjskim archipelagu arktycznym. Średnia roczna temperatura powietrza na obszarze środkowej Arktyki wynosi ok. $-18^{\circ} \mathrm{C}$ (Ryc. 2). Temperatura powietrza najchłodniejszych miesięcy (styczeń-luty) waha się od poniżej $-50^{\circ} \mathrm{C}$ we wnętrzu Grenlandii, $-35-30^{\circ} \mathrm{C} \mathrm{w}$ Arktyce syberyjskiej (np. Tiksi) i kanadyjskiej (np. Coppermine), do ok. $-8^{\circ} \mathrm{C}$ w atlantyckiej części Arktyki (Ryc. 3). Natomiast średnia temperatura najcieplejszego miesiaca (lipca) wynosi od poniżej $0^{\circ} \mathrm{C}$ we wnętrzu Grenlandii do ok. $10^{\circ} \mathrm{C}$ na południowych granicach Arktyki, np. Kanin Nos, Coppermine lub Tiksi (Ryc. 3).

Najnowsze badania pokazuja, że wzrost średniej temperatury powietrza w Arktyce w latach 1979-2019 był trzykrotnie wyższy niż średni globalny w tym okresie (AMAP 2021). $Z$ badań PRZYBYLAKA (2002, 2007a, b, 2016) wynika, że znaczące ocieplenie w Arktyce (o ok. $1^{\circ} \mathrm{C}$ ) rozpoczęło się $z$ około 20-letnim opóźnieniem w stosunku do globalnego ocieplenia (od połowy lat 70. XX w.). Temperatura powietrza po 1995 r. w Arktyce osiaga porównywalne, a nawet wyższe wartości w stosunku do ocieplenia notowanego w latach 30. i 40. XX wieku (Ryc. 4). Według PRZYBYLAKA i WYSZYŃSKIEGO (2020) skala ocieplenia w Arktyce w latach 1996-2015. w stosunku do okresu referencyjnego 1951-1990. osiagnęła $1,6^{\circ} \mathrm{C}$ dla średniej rocznej i była naj- 


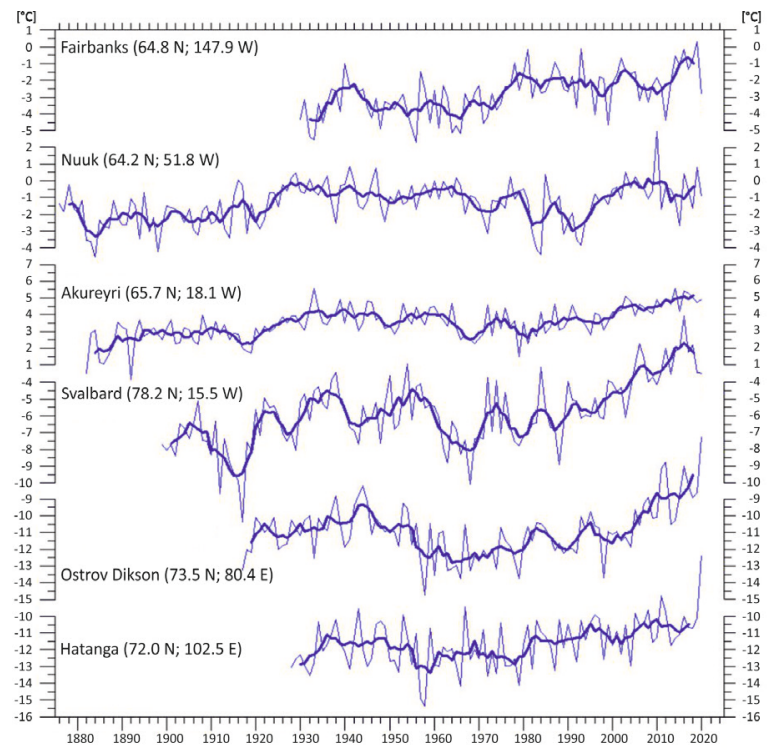

Ryc. 4. Średnie roczne wartości temperatury powietrza w wybranych stacjach w Arktyce: Fairbanks (Alaska), Nuuk (Grenlandia), Akureyri (Islandia), Svalbard (Norwegia), Ostrov Dikson (Syberia) i Hatanga (Syberia). Źródło: NASA Goddard Institute for Space Studies (GISS) and Rimfrost (http://www.climate4you.com/).

większa jesienia $\left(1,9^{\circ} \mathrm{C}\right)$ i zima $\left(1,7^{\circ} \mathrm{C}\right)$, natomiast najmniejsza latem $\left(0,9^{\circ} \mathrm{C}\right)$. Największe ocieplenie zaobserwowano w rejonach: atlantyckim i syberyjskim, podczas gdy w pozostałej części Arktyki tempo ocieplenia było słabsze.

Temperatura powietrza w latach 19962015, w stosunku do okresu 1951-1990, wzrosła o ok. $1,5^{\circ} \mathrm{C}$ w prawie całej Arktyce, $z$ wyjątkiem południowych kontynentalnych i przybrzeżnych części kontynentu euroazjatyckiego i rozciagajacych się na południe obszarów od Zatoki Hudsona do wyspy Jan Mayen (PRZYBYLAK i WYSZYŃSKI 2020). Największe ocieplenie $\left(>2,5^{\circ} \mathrm{C}\right)$ stwierdzono między Svalbardem a Ziemią Franciszka Józefa. Autorzy stwierdzili m.in. iż obszar ten charakteryzował się również największym ociepleniem zimowym $\left(>3,5^{\circ} \mathrm{C}\right)$ i wiosennym $\left(>2,5^{\circ} \mathrm{C}\right)$. Duży wzrost temperatury powietrza zima na tym obszarze został także odnotowany przez innych autorów: ALEXEEV i współaut. (2017), JUNG i współaut. (2017) oraz KoHNEMANN i współaut. (2017). Ocieplenie w tym regionie było prawdopodobnie spowodowane zmiana cyrkulacji atmosferycznej. Notuje się częstsze napływy mas ciepłego powietrza $z$ południa do Morza Barentsa (AlEXEeV i współaut. 2017, YUROVA i współaut. 2018).

W 2020 r. odnotowano rekordowe wartości temperatury powietrza w różnych regionach Arktyki. W syberyjskim Wierchojańsku

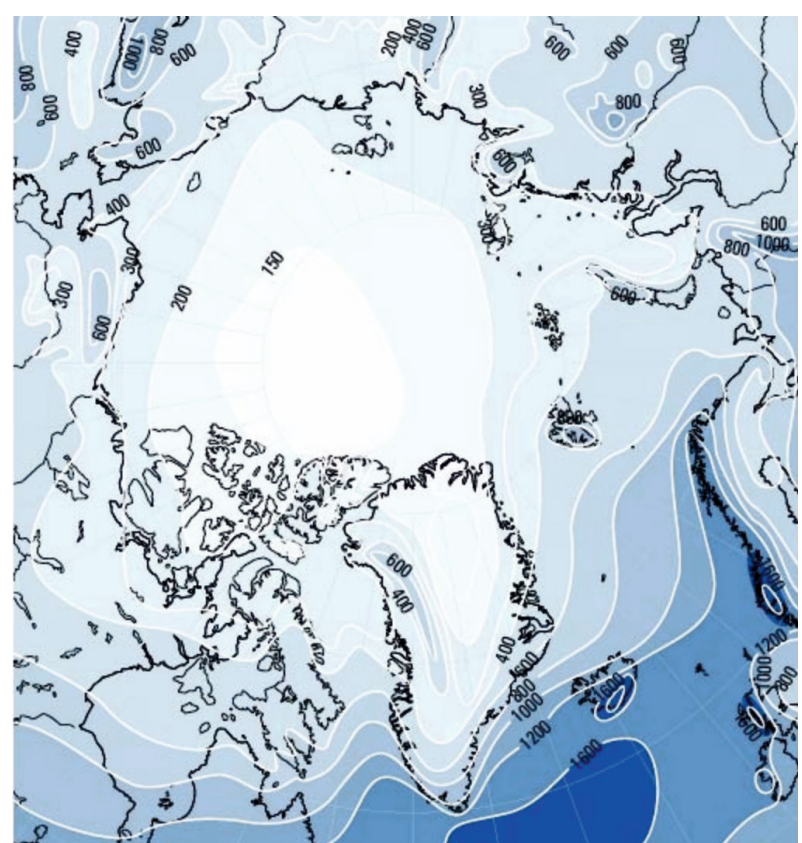

Ryc. 5. Sumy roczne opadów atmosferycznych (mm) w Arktyce (TRESHNiKOV 1985)

zmirzono rekordowa wartość dla całej Arktyki, wynoszaca $38,0^{\circ} \mathrm{C}$ (https://public.wmo. int/en/media/news / reported-new-recordtemperature-of-38\%C2\%BOc-north-of-arcticcircle). W związu $z$ wysokimi temperaturami latem 2020 r. rejon Syberii dotknęła również bezprecedensowa seria pożarów. Rekordy ciepła zanotowano także w innych obszarach Arktyki, m.in. na Spitsbergenie. W Longyearbyen zanotowano najwyższa temperature powietrza $\left(21,7^{\circ} \mathrm{C}\right)$ w historii pomiarów (https://www.severe-weather.eu/news / svalbard-record-heat-norway-mk).

Opady atmosferyczne sa bardzo ważnym elementem klimatycznym. Opady, w przeciwieństwie do temperatury powietrza, charakteryzują się niezwykle dużą zmiennościa zarówno w czasie, jak i w przestrzeni. W Arktyce pomiar opadów jest bardzo trudny i w wskutek niedoszacowania mierzone wartości moga być mniejsze nawet do 40\% (PRZYBYLAK 2016), a wyznaczane sumy i trendy moga być obarczone znacznymi błędami (FøRLAND i HANSSEN-BAUER 2003).

Opady w Arktyce sa przeważnie małe, ponieważ powietrze zawiera niewielkie ilości pary wodnej. W Arktyce sumy roczne opadów wynoszą od poniżej $100 \mathrm{~mm}$ w części środkowej, do ponad $400 \mathrm{~mm}$ na granicach południowych. Najwięcej opadów notowano w atlantyckim sektorze Arktyki między Grenlandią a Skandynawią (Ryc. 5). Ośrodki cyklonalne tworzace się na Oceanie Atlantyckim przynosza wilgotne masy powietrza na ten obszar, zwłaszcza zima (m.in. TRESHNIKOV 1985; ARAŹNY 2008; PRZYBYLAK 2002, 


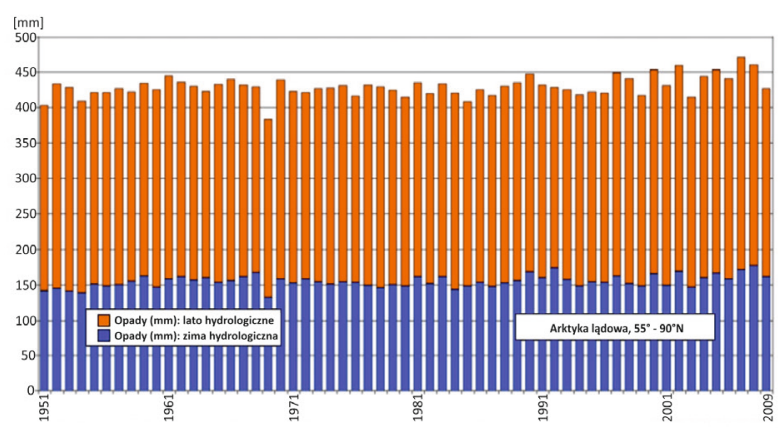

Ryc. 6. Sumy roczne opadów atmosferycznych (mm) w okresie 1951-2009 wg danych ze stacji lądowych w Arktyce $\left(55-90^{\circ} \mathrm{N}\right)$ podczas lata hydrologicznego (pomarańczowe słupki) i zimy hydrologicznej (niebieskie słupki). Na podstawie danych: Global Precipitation Climatology Center/WMO/ Deutscher Wetterdienst (Walsh i współaut. 2011).

2016). Opady w Arktyce wykazuja silna sezonowość, która różni się w zależności od regionu, $z$ maksimum zimowym i minimum letnim na północnym Atlantyku i odwrotnie na lacdowej Arktyce i środkowym Oceanie Arktycznym (SERREZE i współaut. 2005, VIHMA i współaut. 2016, YU i ZHONG 2021).

$\mathrm{Na}$ większości obszarów Arktyki lądowej zarówno obserwacje (HANSSEN-BAUER i FøRLAND 1998; PRZYBYLAK 2002, 2016; KHON i współaut. 2007), jak i symulacje modeli klimatycznych (KATTSOV i współaut. 2007) wykazały rosnacy trend opadów, szczególnie w okresie zimowym. W XXI w. kierunki i wielkość trendów w opadach Arktyki są bardzo zmienne w zależności od okresów, regionów i pór roku (VIHMA i współaut. 2016; MCAFEe i współaut. 2013, 2014; Yu i ZHONG 2021). Jedna $z$ ważniejszych serii pomiarów opadów atmosferycznych, in situ w Arktyce, pochodzi $z$ bazy Global Precipitation Climatology Center (GPCC). Na Ryc. 6 przedstawiono średnie sumy opadów dla obszarów lądowych na północ od $55^{\circ} \mathrm{N}$ podczas zimy (październik-marzec) i lata (kwiecień-wrzesień). W okresie 1951-2009 stwierdzono niewielki wzrost opadów, ale nie istotny statystycznie (WALSH i współaut. 2011). W badanym okresie zwraca uwage fakt, iż pięć najbardziej wilgotnych lat (ponad $450 \mathrm{~mm}$ ) wystapiło w latach 2000-2008 (Ryc. 6).

\section{ZMIANY KLIMATU W POLSKIEJ} STACJI POLARNEJ IM. STANISEAWA SIEDLECKIEGO W HORNSUNDZIE (POŁUDNIOWY SPITSBERGEN)

W ostatnich dekadach gwałtowne zmiany klimatu i środowiska Arktyki znajduja odzwierciedlenie w seriach danych gromadzonych w ramach monitoringu meteorolo-

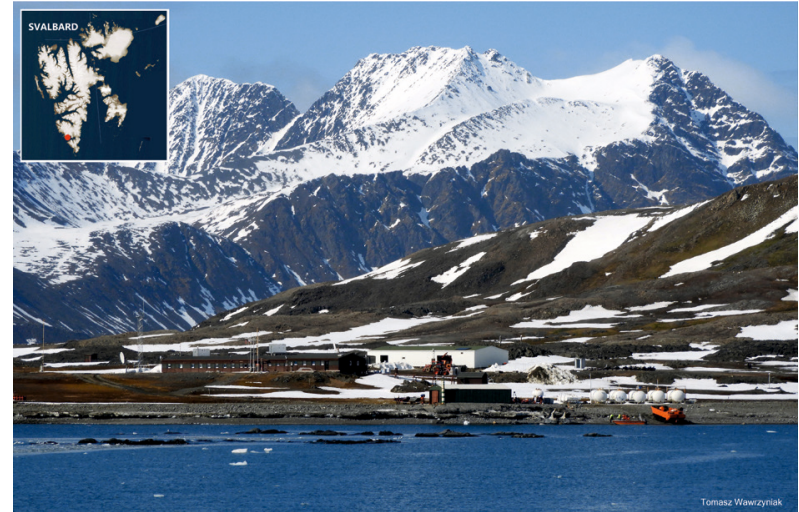

Ryc. 7. Polska Stacja Polarna Hornsund na Spitsbergenie (fot. T. Wawrzyniak).

gicznego prowadzonego w Polskiej Stacji Polarnej im. Stanisława Siedleckiego w Hornsundzie, zarzadzanej przez Instytut Geofizyki Polskiej Akademii Nauk. Stacja ta została założona w 1957 r. w południowej części Spitsbergenu, największej wyspy archipelagu Svalbard i funkcjonuje nieprzerwanie od lipca 1978 r. Jest to jedyne całoroczne polskie obserwatorium w Arktyce (Ryc. 7).

Pomiary warunków meteorologicznych sa prowadzone we współpracy $z$ Norweskim Instytutem Meteorologicznym, a informacje o pogodzie sa na bieżaco raportowane do Światowej Organizacji Meteorologicznej (WMO). Stacja Hornsund funkcjonuje pod numerem 01003, a wszelkie obserwacje i pomiary wykonywane sa zgodnie $z$ obowiazującymi w WMO standardami (MARSZ i STYSZYŃSKA 2013, WAWRZYNIAK i OSUCH 2020). Ogródek meteorologiczny stacji Hornsund $\left(77^{\circ} 00^{\prime} \mathrm{N}, \quad 15^{\circ} 33^{\prime} \mathrm{E}\right) \quad z$ automatyczna stacja MAWS 301 jest położony na wyniesionej terasie morskiej na wysokości $10 \mathrm{~m}$ n.p.m.,
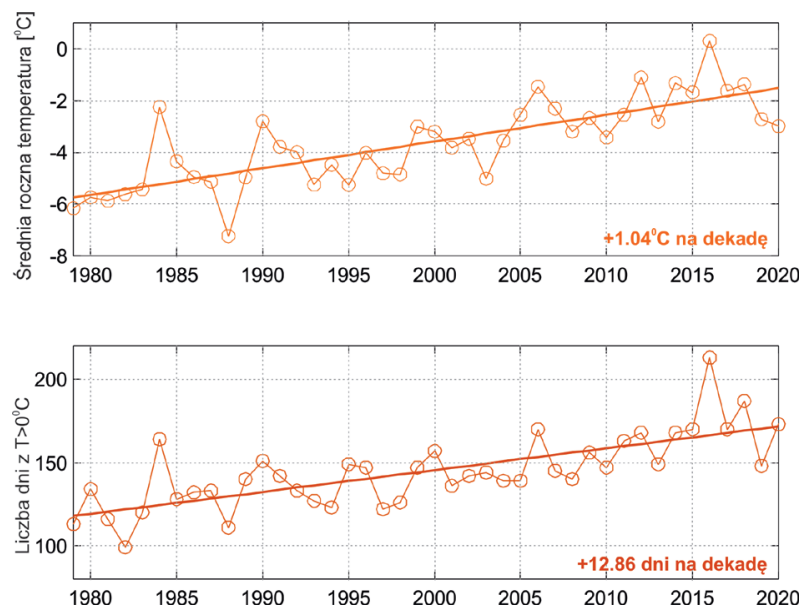

Ryc. 8. Zmienność średniej rocznej temperatury powietrza oraz liczba dni $z$ dodatnimi temperaturami powietrza w Hornsundzie w okresie 19792020. 
w odległości ok. 300 metrów od brzegu fiordu Hornsund. Dane $z$ Hornsundu służą do tworzenia prognoz pogody oraz informuja o zmienności warunków klimatycznych w atlantyckim sektorze Arktyki. Pomiary meteorologiczne sa też niezbędnym elementem dla wszelkich prowadzonych tu badań, mię$\mathrm{dzy}$ innymi $z$ zakresu hydrologii, glacjologii, geomorfologii, a także ornitologii czy biologii tundry.

Zmiany temperatury powietrza obserwowane w Hornsundzie odzwierciedlaja globalny trend ocieplenia, ale jest tu ono znacznie intensywniejsze niż w niższych szerokościach geograficznych. $\mathrm{Na}$ Ryc. 8 przedstawiono zmienność średniej rocznej temperatury w okresie 1979-2020. Istotność trendu oszacowano zmodyfikowanym testem Manna-Kendalla (MANN 1945, KENDALL 1975, HAMED i RAO 1998) Z uwzględnieniem autokorelacji szeregów czasowych. Nachylenie trendu oszacowano metoda Sena (SEN 1968), gdzie nachylenie obliczane jest jako mediana nachyleń wszystkich par punktów. Wyraźnie widoczny i statystycznie istotny trend wzrostowy temperatury powietrza, który wynosi $1,04^{\circ} \mathrm{C}$ na dekadę. Jest to jeden $z$ najwy $\dot{-}$ szych wzrostów średniej temperatury rocznej na świecie, kilkukrotnie wyższy niż średnia globalna $\left(+0,18^{\circ} \mathrm{C}\right.$ na dekadę) $\mathrm{w}$ tym samym okresie (NOAA 2021). Średnia roczna temperatura powietrza w Hornsundzie wzrosła w ciagu ostatnich czterdziestu lat aż o ponad $4^{\circ} \mathrm{C}, z$ poniżej -6 do około $-2^{\circ} \mathrm{C}$.

Dodatkowo, na podstawie średniej dobowej temperatury wyznaczono liczbę dni $z$ dodatnimi temperaturami w ciagu roku kalendarzowego w okresie 1979-2020. Wskaźnik ten ma znaczne implikacje środowiskowe. Istotny statystycznie jest też trend liczby dni $z$ dodatnimi temperaturami. Wynosi on $+12,84$ dni na dekadę, co oznacza, iż od początku pomiarów w Hornsundzie liczba tych dni w ciagu roku wzrosła o ponad 50 .

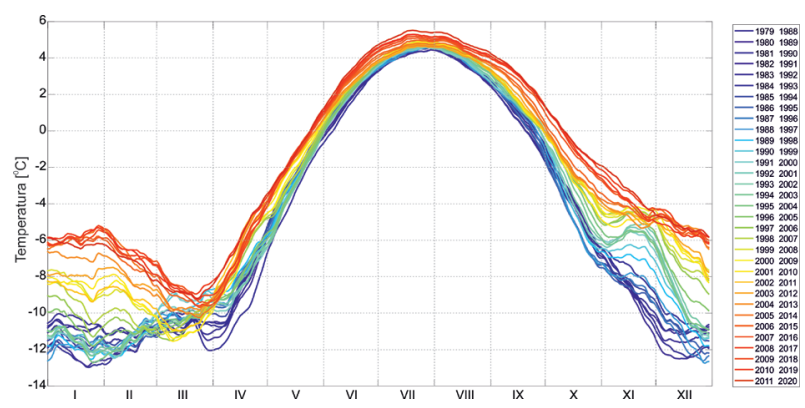

Ryc. 9. Zmienność sezonowa średniej dobowej temperatury powietrza w Hornsundzie w okresie 1979-2020, uśredniona za pomoca metody MASH.
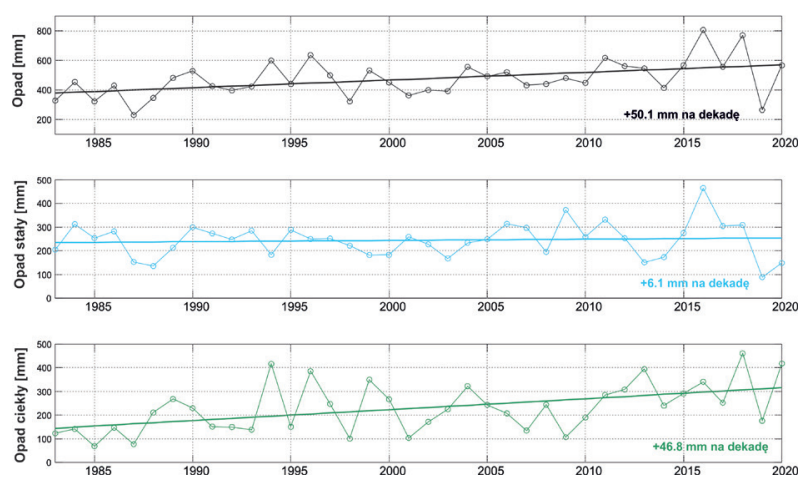

Ryc. 10. Zmienność rocznej sumy opadu atmosferycznego w Hornsundzie w okresie 1983-2020.

W celu rozpoznania zmienności sezonowej zastosowano metodę Moving Average over Shifting Horizon (MASH). Metoda ta pozwala wykryć trendy i zmiany sezonowości poprzez odfiltrowanie efektów lokalnych oraz drobnoskalowych (ANGHILERI i współaut. 2014, OSUCH i WAWRZYNIAK 2017, WAWRZYNIAK i współaut. 2021). Metodę MASH zastosowano do analizy średniej dobowej temperatury powietrza $z$ okresu 1979-2020 (Ryc. 9) oraz dobowych sum opadów z okresu 1983-2020 (patrz Ryc. 11). Rycina 9 prezentuje temperatury powietrza dla każdego dnia w roku, uśrednione w dwóch horyzontach po 30 dniach i po 10 latach. Za pomoca koloru linii pokazano dekady, dla których uśredniono dane. Kolorem granatowym oznaczone sa dane $z$ lat 80 . XX w., natomiast kolorem czerwonym dane $z$ XXI w. Poprzez porównanie przebiegu tych linii oceniono zmiany sezonowości temperatury powietrza. Wyniki pokazuja, że tendencje zmian nie rozkładaja się równomiernie w ciąu roku. Średnie miesięczne temperatury wynosza latem około $5,0^{\circ} \mathrm{C}$, natomiast zima i wiosna charakteryzują się większymi amplitudami do-

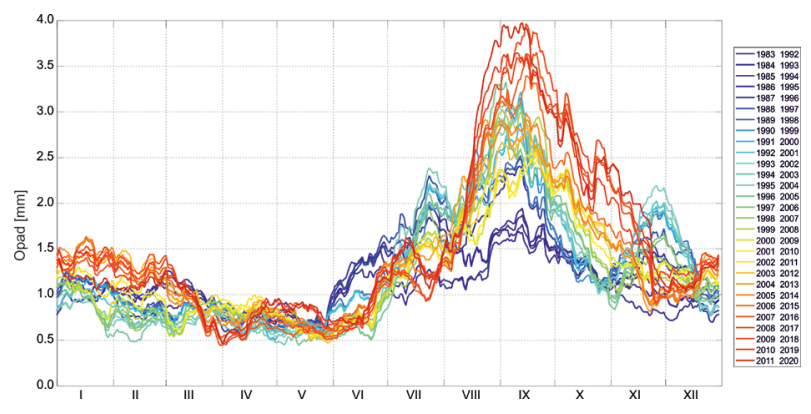

Ryc. 11. Zmienność sezonowa dobowych sum opadu atmosferycznego w Hornsundzie w okresie 1983-2020, uśredniona za pomoca metody MASH. 
bowymi temperatury. Dla wszystkich dni w roku oszacowano tendencje wzrostowe temperatury powietrza, $z$ największymi zmianami w okresie jesienno-zimowym i niewielkimi zmianami w okresie letnim.

Uwzględniając poszczególne miesiące, największe zmiany temperatury powietrza wystapily $\mathrm{w}$ styczniu, lutym $\mathrm{i}$ grudniu (większe niż $2,0^{\circ} \mathrm{C}$ ). Najmniejsze zmiany zaobserwowano $\mathrm{w}$ miesiaccach letnich, lipcu i sierpniu, $z$ nachyleniem trendu $0,3^{\circ} \mathrm{C}$ na dekadę. W porównaniu do początków obserwacji zmienił się również kształt rocznego biegu temperatury powietrza, $z$ przesunięciem najzimniejszych miesięcy $z$ grudnia $i$ stycznia na marzec i kwiecien. W latach 80. okres topnienia, $z$ dodatnia temperatura, trwał od pierwszej dekady czerwca do ostatniej dekady września, aktualnie zwykle od ostatniej dekady maja do połowy października.

Szeregi czasowe opadów atmosferycznych w Hornsundzie obejmuja okres od 1979 r. do 2020 r., istnieje jednak przerwa $\mathrm{w}$ danych w lipcu 1982 r., stąd analizy obejmuja okres 1983-2020. Na rycinie 10 przedstawiono zmienność rocznej sumy opadu, z wydzieleniem opadu ciekłego i stałego. Jak widać opady deszczu wzrosły o 46,8 $\mathrm{mm}$ na dekade, przy nieistotnym statystycznie wzroście opadów stałych o $6,1 \mathrm{~mm}$. W analizowanym okresie roczna suma opadów wzrosła o 50,1 $\mathrm{mm}$ na dekadę. Biorac pod uwagę zmienność sezonowa (Ryc. 11) widoczny jest największy wzrost ilości opadów w okresie od drugiej połowy sierpnia do połowy listopada.

\section{WPEYW ZMIAN KLIMATU NA EKOSYSTEMY W ARKTYCE}

Zmiany klimatu oddziałuja na bardzo wrażliwe ekosystemy polarne. Obszary polarne sa bardzo podatne na zmiany klimatu ze względu na liczne sprzężenia zwrotne. Stwarza to zagrożenia dla ekosystemu Arktyki, ale też i dla całego świata (PRZYBYLAK 2016; AMAP 2017, 2021; PRZYBYLAK i WYSZYŃSKI 2020; IPCC 2021).

W Arktyce obserwuje się znaczne zmniejszanie zasięgu i grubości lodów morskich. Powoduje to zmiany albeda (stosunek ilości promieniowania odbitego do padajacego) i wzrost absorpcji promieniowania słonecznego. Ponadto, zmniejszenie powierzchni oceanu zajętej przez lód morski oraz skrócenie sezonu $z$ pokrywa lodowa intensyfikuje proces oddawania ciepła zgromadzonego i przetransportowanego przez wody oceanu (SERREZE i BARRY 2011). W Arktyce w przebiegu rocznym najmniej lodu jest we wrześniu. Pokrywa lodowa zajmuje wtedy około $6 \mathrm{mln}$ $\mathrm{km}^{2}$ (średnia dla lat 1979-2019) (Comiso

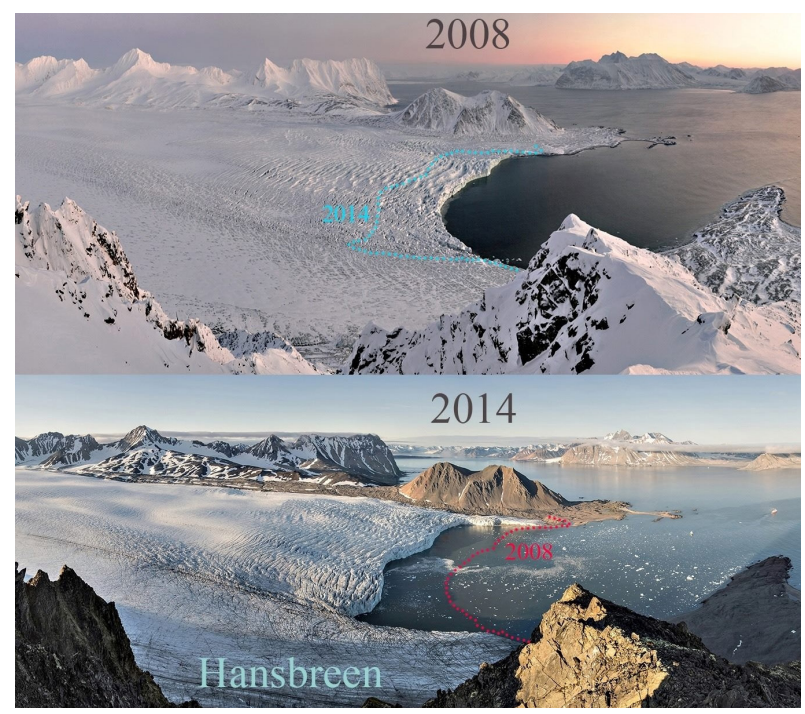

Ryc. 12. Recesja Lodowca Hansa na Spitsbergenie (fot. W. Kaszkin). Objaśnienie: Lodowiec Hansa w latach 1992-2015 wycofał się ponad 1000 metrów.

2012, IPCC 2021). Jesienia 2012 r. pokrywa lodu morskiego w Arktyce zajmowała jedynie 3,34 $\mathrm{mln}^{2}$. Prognozy na przyszłość sa takie, że arktyczny lód morski najprawdopodobniej całkowicie stopnieje do 2035 r. (GUARINO i współaut. 2020).

Szybki ubytek lodu morskiego może być spowodowany m.in. przez wzmożony napływ ciepłych wód atlantyckich do Arktyki (WALCZOWSKI i PIECHURA 2011, AMAP 2017). Pomiary temperatury wody wykonane przez Instytut Oceanologii PAN w transekcie wzdłuż $76,5^{\circ} \mathrm{N}$ w okresie 2000-2007 wykazuja 92\% korelacje $z$ temperatura powietrza w Hornsundzie $\left(77^{\circ} \mathrm{N}\right)$ na południowym Spitsbergenie (WALCZOWSKI i PIECHURA 2011). Relacje te potwierdzaja istotny wpływ termiki wód oceanicznych na kształtowanie klimatu regionu Arktyki Norweskiej.

Zmniejsza się grubość i powierzchnia lodowców kontynentalnych Arktyki. Również lodowce w Arktyce Atlantyckiej szybko reaguja na zmieniajacce się warunki klimatyczne. Średnie tempo recesji lodowców wzrosło z 30,5 m/rok w latach 1992-2000 do 106 $\mathrm{m} /$ rok w okresie 2000-2010 (CARR i współaut. 2017). Podobne wyniki uzyskała BŁASzCZYK i współaut. (2013) dla basenu fiordu Hornsund (południowy Spitsbergen) (Ryc. 12). W latach 1936-1976 tempo recesji powierzchniowej lodowców wzrosło do ok. 1,6 $\mathrm{km}^{2} /$ rok, po roku 2000 od $2,6 \mathrm{~km}^{2} /$ rok, a w ostatnich latach aż do $3,5 \mathrm{~km}^{2} /$ rok. Znaczą recesję obserwuje się również w północno-zachodnim Spitsbergenie (SOBOTA 2013). Przykładowo, czoło Lodowca Waldemara cofało sie w okresie 1995-2000 w tempie 6 $\mathrm{m} /$ rok, a w latach 2000-2010 o $11 \mathrm{~m} /$ rok. 
Znaczne przyspieszenie deglacjacji w XXI w. powoduje zmiany linii brzegowej i przybrzeżnej obszarów lądowych w Arktyce. ZIAJA i OsTAFIN (2019) stwierdzili, że od lat 60. XX w. powstały 34 nowe wyspy o powierzchni równej lub większej niż $0,5 \mathrm{~km}^{2}$. Najwięcej (26) nowych wysp pojawiło się u wybrzeży Grenlandii. Na Ziemi Franciszka Józefa i Nowej Ziemi w rosyjskiej części Arktyki wyłoniło się ich sześć. Jedna wyspa powstała w archipelagu Svalbard.

Ocieplenie Arktyki powoduje przyspieszone topnienie wieloletniej zmarzliny w różnych jej regionach (SOBOTA 2013, AMAP 2017, IPCC 2021). Odmarzajacy grunt emituje duże ilości dwutlenku węgla i metanu, które zwiększaja efekt cieplarniany.

$\mathrm{Na}$ terenach odsłoniętych od lodu formuja się zbiorowiska roślinne i zachodza przemiany w składzie gatunkowym roślinności w Arktyce (m.in. ZIAJA i współaut. 2011; CAFF 2013; OlECH i współaut. 2011, 2013). W wielu rejonach arktycznych sukcesja roślinności zachodzi szybko, często w ciagu 20-30 lat zajmuje ona nowe tereny (ZIAJA i współaut. 2011). W wielu regionach Arktyki w ciagu ostatnich dwudziestu lat można zaobserwować rozrost roślinności tundrowej (BUCHWAe i współaut. 2020).

W Arktyce zmienia się zasięg gatunków fauny arktycznej (CAFF 2013, DESCAMPS i współaut. 2017). Na przykład zagrożona jest populacja niedźwiedzia polarnego, powszechnego symbolu zmian klimatycznych. Jego występowanie jest związane $z$ obecnościa lodu morskiego (REGEHR i współaut. 2016).

Ocieplenie klimatu w regionach polarnych stwarza możliwość rozpoczęcia „przemysłowej" eksploracji zasobów mórz i dna morskiego (od gazu ziemnego i ropy naftowej, po ryby $z$ bogatych lowisk). Niesie to realne, większe niż $\mathrm{w}$ innych regionach, niebezpieczeństwo degradacji unikatowego i nie do końca zbadanego ekosystemu polarnego.

Zmiany klimatu $w$ Arktyce powoduja również polepszenie odczuwalnych warunków pogodowych dla człowieka (ARAŹNY 2008, 2019).

\section{ZMIANY KLIMATU W ANTARKTYCE}

Antarktyka, obejmujaca kontynent Antarktydy i Ocean Południowy (Ryc. 13), stanowi istotny element systemu klimatycznego kuli ziemskiej (KING i TURNeR 1997). Zachodzace zmiany klimatu $\mathrm{w}$ tym rejonie wpływaja na stan środowiska przyrodniczego tego ekosystemu (TURNER i współaut. 2013a). Badania zmian klimatu w Antarktyce sa utrudnione ze względu na krótkie serie pomiarowe. Wykorzystywane sa dane posrednie, np. informacje zawarte $\mathrm{w}$ rdzeniach

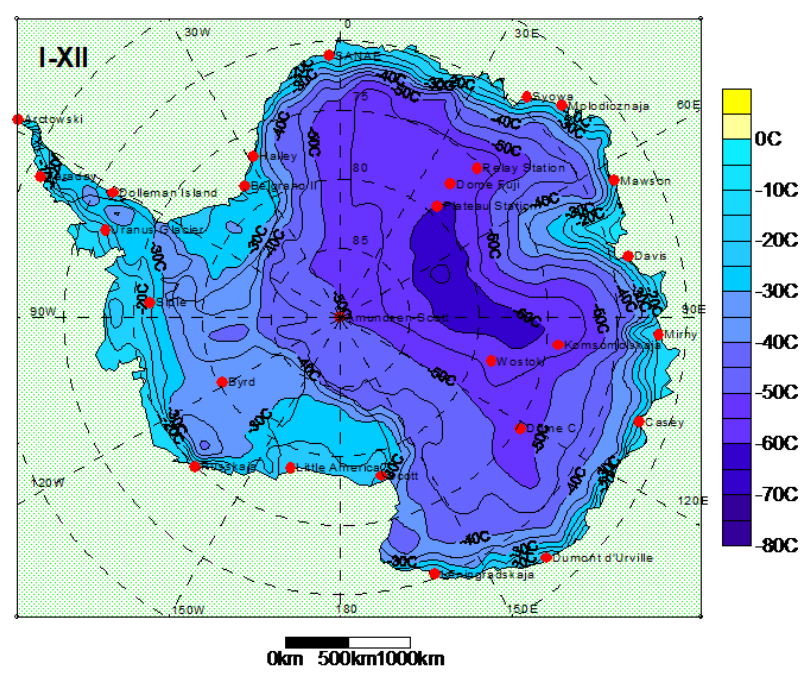

Ryc. 13. Rozkład przestrzenny średniej rocznej temperatury powietrza na Antarktydzie w latach 1958-2000 (KEJNA 2008).

lodowych (MAYEwSKI i współaut. 2009). Najwcześniej regularne pomiary meteorologiczne rozpoczęto na stacji Orcadas (1903) położonej na Oceanie Południowym. Na kontynencie serie pomiarowe sa jeszcze krótsze, większość stacji pomiarowych rozpoczęła działalność w ramach Międzynarodowego Roku Polarnego (1957-1959). Stacje sa w większości położone na wybrzeżu. W rozległym wnętrzu kontynentu działaja obecnie 3 stacje: rosyjska stacja Vostok, amerykańska Amundsen-Scott i europejska Concordia. Od lat 80. $\mathrm{XX}$ w. założono sieć stacji automatycznych (LAZZARA i współaut. 2012).

W analizie wykorzystano dane zamieszczone w bazie Antarctic Data for Environmental Reasearch (READER) (TURNER i współaut. 2004). Sa one dostępne online na stronie https://legacy.bas.ac.uk/met/READER. Dane o opadach atmosferycznych w rosyjskich stacjach antarktycznych pochodza $z$ bazy Arctic and Antarctic Research Institute (http://www.aari.aq/default_en.html). Niestety $\mathrm{w}$ niektórych stacjach występuja braki w danych, bąż́ też średnie sa obliczane na podstawie niepełnych danych. Dlatego też $\mathrm{w}$ analizie uwzględniono dane $z$ lat 1958-2020, a dla stacji o krótszym okresie działalności od początku pomiarów do $2020 \mathrm{r}$.

Na Antarktydzie występuja najniższe temperatury powietrza na kuli ziemskiej. Jak wykazały badania dla lat 1958-2000 (KEJNA 2008) we wnętrzu kontynentu średnia roczna temperatura powietrza może być niższa od $-60^{\circ} \mathrm{C}$. Rekordowo niska temperature minimalna $\left(-89,2^{\circ} \mathrm{C}\right)$ zanotowano w lipcu $1983 \mathrm{r}$. na stacji Wostok (TURNER i wspólaut. 2021). Tak niskie wartości temperatury wynikaja $\mathrm{z}$ braku dopływu promieniowania w czasie 
nocy polarnej, śnieżno-lodowcowego podłoża charakteryzujacego się wysokim albedo i silnego wypromieniowania przez cienka atmosferę (plateau Antarktydy Wschodniej wznosi się na ponad $4000 \mathrm{~m}$ n.p.m.). Nawet latem średnie miesięczne wartości temperatury sa ujemne, a rekordowo wysoka wartość temperatury na stacji Wostok nie przekroczyła $-14,4^{\circ} \mathrm{C}$. Również na wybrzeżu występuja bardzo niskie wartości temperatury powietrza. Średnio rocznie wynosza one od -10 do $-20^{\circ} \mathrm{C}$. Jest to efekt częstej adwekcji mroźnych mas powietrza $z$ wnętrza kontynentu (wiatr katabatyczny) i słabego oddziaływania Oceanu Południowego, który jest pokryty lodem morskim przez większą część roku. Jedynie na zachodnim wybrzeżu Półwyspu Antarktycznego średnia roczna temperatura powietrza jest wyższa (od -2 do $-5^{\circ} \mathrm{C}$ ). Latem średnie miesięczne na wybrzeżu na terenach niezlodowaconych sa dodatnie, ale nie przekraczaja kilku stopni powyżej zera (Ryc. 14). Rekordowo wysokie wartości temperatury występują w rejonie Półwyspu Antarktycznego, na stacji Marambio zmierzono $17,7^{\circ} \mathrm{C}$ (TURNER i współaut. 2021). W lutym 2020 r. na stacji Esperanza zarejestrowano $18,3^{\circ} \mathrm{C}$ (WMO 2021).

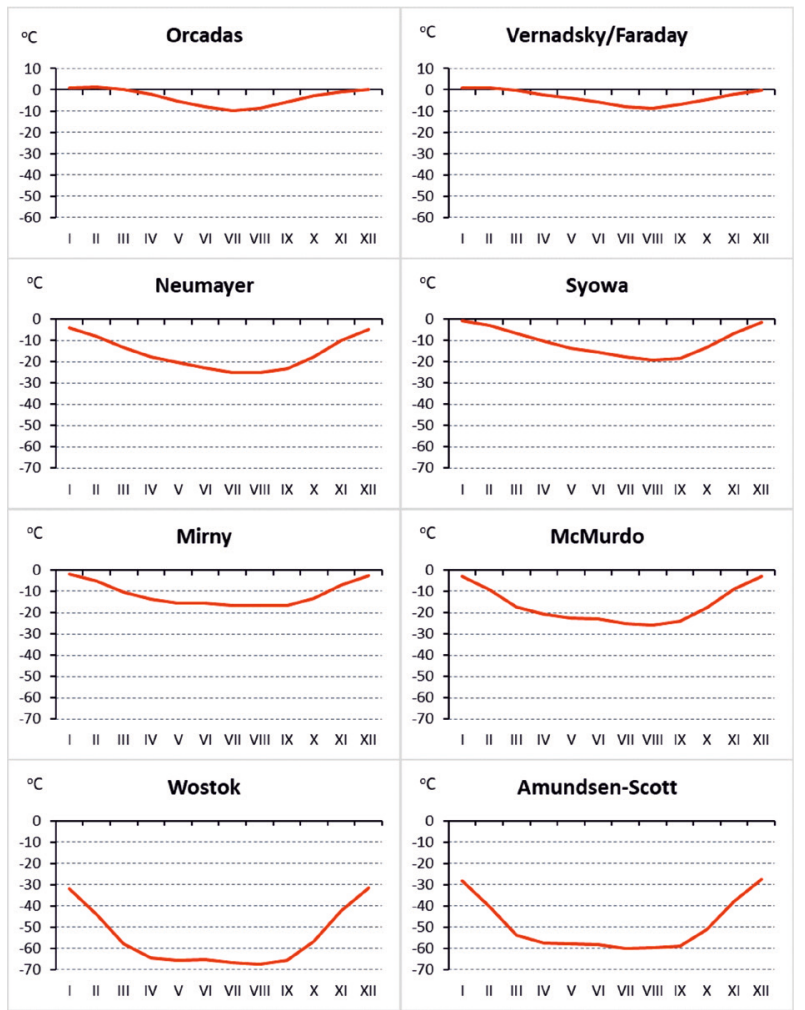

Ryc. 14. Przebieg roczny temperatury powietrza na wybranych stacjach antarktycznych w latach 1958-2020. Dla stacji Neumayer 1980-2020.
Biegunem zima nie tylko dla kontynentu, ale i całej kuli ziemskiej, jest stacja Wostok, gdzie w latach 1958-2020 średnia temperatura wyniosła $-55,1^{\circ} \mathrm{C}$. Na biegunie południowym (stacja Amundsen-Scott) było $-49,3^{\circ} \mathrm{C}$. Najwyższa średnia temperatura wystapiła na stacji Bellingshausen $\left(-2,7^{\circ} \mathrm{C}\right)$ na Półwyspie Antarktycznym. Zima średnia temperatura na stacji Wostok wyniosła $-66,6^{\circ} \mathrm{C}$, a na Półwyspie Antarktycznym $-5,9^{\circ} \mathrm{C}$ (Bellingshausen). Latem tylko na nielicznych stacjach położonych na wyspach (Orcadas $0,8^{\circ} \mathrm{C}$ ) i na Pólwyspie Antarktycznym (Bellingshausen, Rothera po $0,7^{\circ} \mathrm{C}, \mathrm{Fa}-$ raday/Vernadsky $0,5^{\circ} \mathrm{C}$ ) temperatura jest dodatnia. W przebiegu rocznym temperatury powietrza zaznacza się długotrwała i mroźna zima, zwłaszcza na stacjach położonych we wnętrzu kontynentu (Ryc. 14).

Warunki klimatyczne na Antarktydzie nie sa stabilne (MAYEWSKI i współaut. 2009). Jak wykazała analiza danych $\mathrm{z}$ rdzeni lodowcowych pobranych na Antarktydzie, na przestrzeni 800 tys. lat wystepowały okresy chłodne (glacjalne) przedzielone krótkimi okresami cieplejszymi (interglacjałami). W okresach chłodnych zawartośc $\mathrm{CO}_{2}$ w powietrzu malała do $180 \mathrm{ppm}$, a globalna temperatura obniżała się do $10^{\circ} \mathrm{C}, \mathrm{w}$ czasie okresów ciepłych było $280 \mathrm{ppm} \mathrm{CO}_{2}$ i temperatura sięgała $15^{\circ} \mathrm{C}$ (TURNER i współaut. 2013a). Badania rdzeni lodowcowych na Wyspie James Rossa wykazały, że optimum temperatury wystapiło we wczesnym Holocenie (9,2-2,5 tys. lat temu) (Holocen - współczesny okres interglacjalny). Następnie nastapiło ochłodzenie $\mathrm{i}$ od ok. 600 lat obserwujemy wzrost temperatury (MULVANEY i współaut. 2012).

$\mathrm{Na}$ tle innych rejonów kuli ziemskiej Antarktyda wykazuje większa odporność na postępujące zmiany klimatu. Spośród analizowanych 17 stacji antarktycznych na 11 stwierdzono istotny statystycznie $(p \leq 0,05)$ wzrost średniej rocznej temperatury powietrza. Największe ocieplenie wystapiło na stacjach położonych na Półwyspie Antarktycznym: Faraday/Vernadsky $\left(0,47^{\circ} \mathrm{C} / 10\right.$ lat $)$, Rothera $\left(0,46^{\circ} \mathrm{C} / 10\right.$ lat) i na Orkadach $\mathrm{Pd}$. (Orcadas $0,20{ }^{\circ} \mathrm{C} / 10$ lat). We wnętrzu kontynentu ocieplenie $\left(0,20^{\circ} \mathrm{C} / 10\right.$ lat $)$ wystapiło tylko na stacji Wostok. W wielu rejonach Antarktydy nie stwierdzono istotnego trendu, a w niektórych stacjach występuje ochłodzenie. Największe zmiany temperatury obserwowano w zimie, np. Faraday/Vernadsky $\left(0,98^{\circ} \mathrm{C} / 10\right.$ lat), co oznacza, że w latach 1958-2020 temperatura wzrosła aż o $6,2^{\circ} \mathrm{C}$ (Ryc. 15).

Uzyskane wyniki potwierdzaja wcześniejsze doniesienia (np. RAPER i współaut. 1984; JONES 1995; JACKA i BUDD 1998; KEJNA 


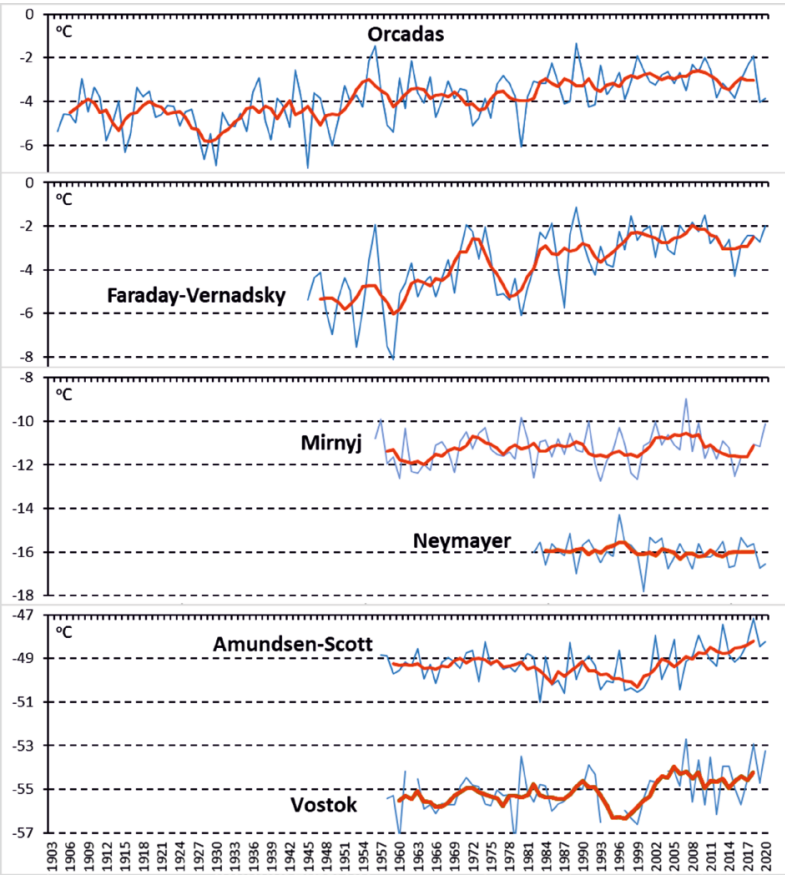

Ryc. 15. Przebieg średniej rocznej temperatury powietrza na wybranych stacjach antarktycznych. Objaśnienia: na czerwono 5-letnia średnia ruchoma.

2003; TURNER i współaut. 2005, 2019. Również dane $z$ Reanaliz potwierdzają znaczne ocieplenie w rejonie Półwyspu Antarktycznego i ochłodzenie na Antarktydzie Wschodniej (ZHU i współaut. 2021).

Opady atmosferyczne należą do trudno mierzalnych elementów meteorologicznych w warunkach polarnych (TANG i współaut. 2018). Stąd też często bada się akumulację śniegu (BROMWICH i współaut. 2004). Antarktyda należy do kontynentów o najmniejszych opadach atmosferycznych na kuli ziemskiej. Najwyższe sumy opadów atmosferycznych występuja na wybrzeżu - do $400 \mathrm{~mm}$. Na Półwyspie Antarktycznym ich suma sięga średnio $625 \mathrm{~mm}$, a w górach nawet do 2000 mm (BROMWICH 1990). Znacznie mniejsze opady występuja we wnętrzu kontynentu i wynosza ok. $20 \mathrm{~mm}$. Sumę opadów atmosferycznych pomniejszonych o sublimację przedstawiono na Ryc. 16. Rozkład przestrzenny opadów na Antarktydzie potwierdzaja dane $z$ reanaliz, najlepsze rezultaty daje ERA-Int (BROMWICH i współaut. 2011). Tak niskie opady sa efektem małej zawartości pary wodnej w powietrzu przy tak niskiej temperaturze. Ponadto, antycyklonalna cyrkulacja atmosferyczna ogranicza rozwój zachmurzenia oraz dopływ wilgotnych mas powietrza $z$ północy. W ciagu roku transport wilgoci sięga od 71 do $170 \mathrm{~mm}$ (BROMWICH

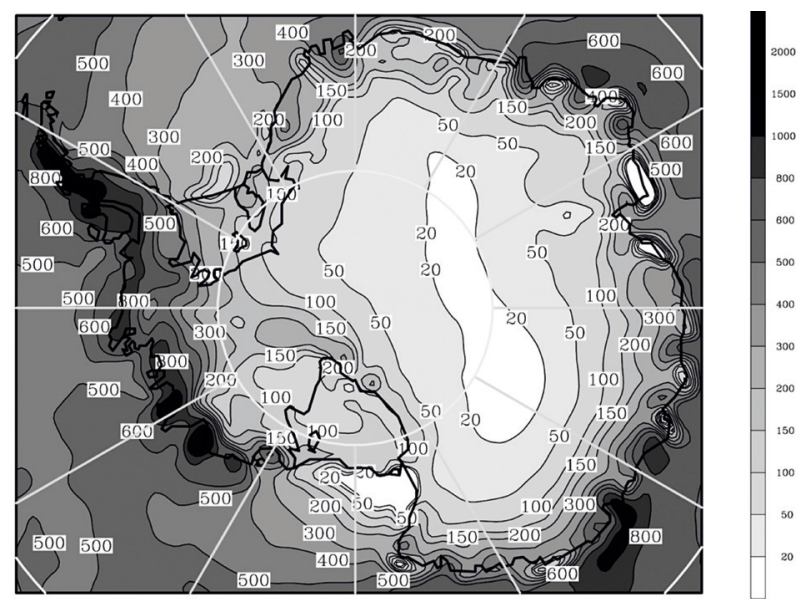

Ryc. 16. Średnie roczne sumy opadów atmosferycznych pomniejszone o sublimację (w $\mathrm{mm}$ ) na Antarktydzie w latach 1996-1999. Źródło mapy: BROMWICH i współaut. 2004.

1990). Istotna rolę w jej przenoszeniu pełnia ośrodki cyklonalne.

W analizie uwzględniono opady atmosferyczne ze stacji rosyjskich udosteppnionych na stronie Arctic and Antarctic Research Institute. Największe opady wystapiły na wybrzeżu Antarktydy Zachodniej (Russkaya 2026,7 mm), również w innych stacjach położonych na wybrzeżu przekraczają one 500 $\mathrm{mm}$, np. Leningradskaya 692,6 mm), jedynie

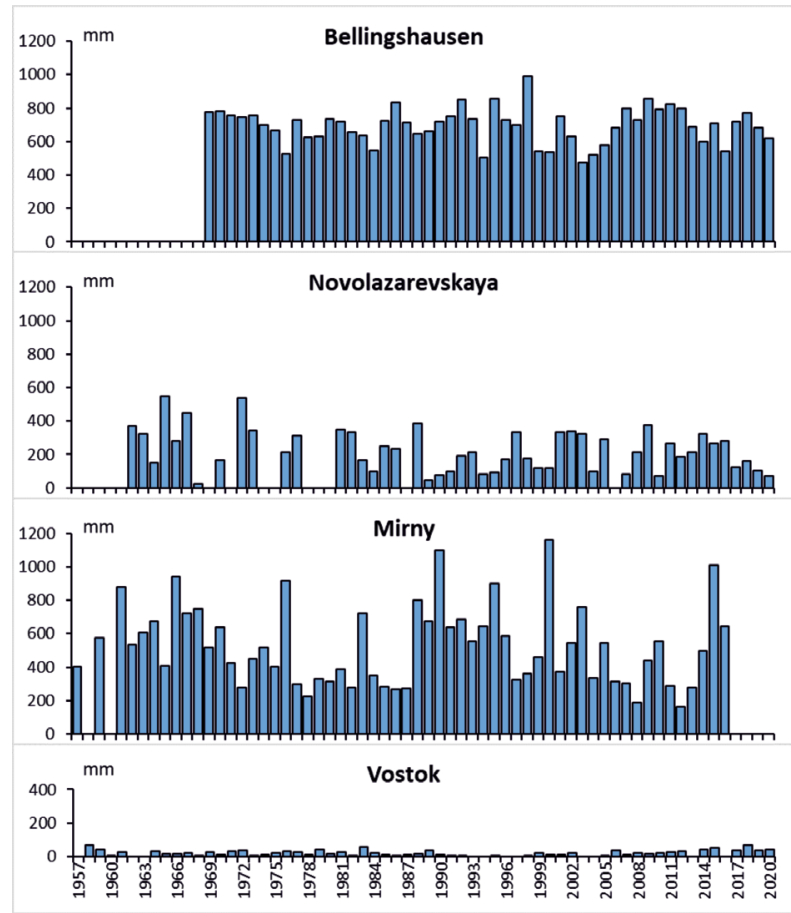

Ryc. 17. Przebieg sum rocznych opadów atmosferycznych na stacjach antarktycznych. 
Novolazarievskaya wykazuje mniejszy opad $(227,5 \mathrm{~mm})$. We wnętrzu kontynentu opady sa znikome, na stacji Wostok ich średnia suma roczna sięga $22,9 \mathrm{~mm}$, a miesięczne opady nie przekraczaja kilku milimetrów.

$\mathrm{Na}$ podstawie dostępnych danych nie stwierdzono istotnie statystycznego trendu wielkości opadów na Antarktydzie (Ryc. 17). Przy ogólnie dużej zmienności opadów $z$ roku na rok występuja okresy $z$ większymi i mniejszymi opadami. Potwierdzaja to badania opadów śniegu (MonAGHAN i współaut. 2006), które nie wykazuja istotnego statystycznie trendu jego akumulacji. W rejonie Półwyspu Antarktycznego (stacja Faraday/ Vernadsky) występuje wzrost liczby dni z opadem, co wynika $z$ pozytywnej fazy SAM (Southern Annular Mode) i zwiększonej cyrkulacji zachodniej. Wraz $z$ ubytkiem lodów morskich w tym rejonie zwiększa się parowanie i częstość występowania opadów (TURNER i współaut. 2005).

ZMIANY KLIMATU W POLSKIEJ STACJI ANTARKTYCZNEJ IM. HENRYKA ARCTOWSKIEGO NA WYSPIE KRÓLA JERZEGO

Polska Stacja Antarktyczna im. Henryka Arctowskiego znajduje się na Wyspie Króla Jerzego w archipelagu Szetlandów Południowych, ok. $120 \mathrm{~km}$ na północ od Półwyspu Antarktycznego. Powierzchnia Wyspy Króla Jerzego jest w ok. 90\% zajęta przez kopuly lodowcowe, $\mathrm{z}$ których $\mathrm{w}$ stronę morza schodza lodowce i lodospady; w najwyższym punkcie wysokość kopuły lodowej wynosi ponad $600 \mathrm{~m}$ n.p.m. Stacja im. H. Arctowskiego, jest położona na zachodnim brzegu Zatoki Admiralicji, na niskiej terasie morskiej, otoczonej od południa i zachodu przez wzniesienia o wysokości ok. 60-170 m n.p.m. (Ryc. 18). Stacja meteorologiczna znajduje się na płaskiej, podmokłej równinie nadmorskiej, ok. $150 \mathrm{~m}$ od głównego budynku Stacji $\left(62^{\circ} 09^{\prime} 32^{\prime \prime} \mathrm{S}, 58^{\circ} 28^{\prime} 04^{\prime \prime W}, 2 \mathrm{~m}\right.$ n.p.m.).

Szetlandy Południowe sa położone w strefie klimatu subantarktycznego morskiego (MARSZ i STYSZYŃSKA 2000), tj. najcieplejszej części Antarktyki. W rejonie Półwyspu Antarktycznego na lokalny klimat mocno wpływaja temperatura powierzchni morza oraz zasięg i rozmieszczenie lodu morskiego (STAMMERJOHN i współaut. 2008, KEJNA i współaut. 2013a, TURNER i współaut. 2013b). Ważnym czynnikiem jest również bardzo częste w tym rejonie przechodzenie ośrodków niskiego ciśnienia (SIMMONDS i współaut. 2003). Czynniki te powoduja dużą zmienność warunków pogodowych w poszczególnych latach. Jest to również je-

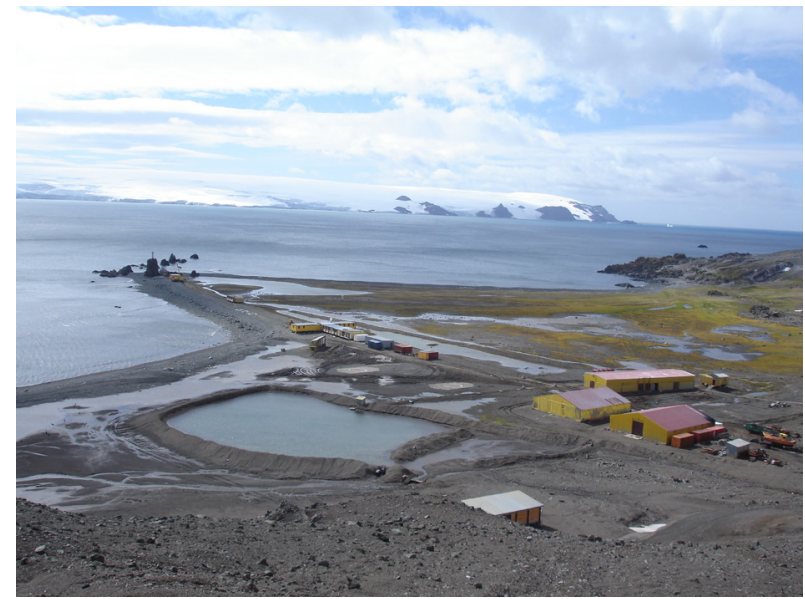

Ryc. 18. Stacja im. H. Arctowskiego w 2012 r. (fot. M. Kejna).

den $z$ najszybciej ocieplających się obszarów na kuli ziemskiej (KEJNA 1999, TURNER i współaut. 2005, STASTNA 2010, CARRASCO 2013, KEJNA i współaut. 2013a). Jednak na początku drugiej dekady XXI w., wystapiło na tym obszarze ochłodzenie, wynikajace ze wzrostu koncentracji lodu morskiego w rejonie Półwyspu Antarktycznego i na Morzu Weddella (TURNER i współaut. 2016, OLIVA i współaut. 2016).

Aby pokazać skalę ocieplenia klimatu w rejonie Stacji Arctowskiego wykorzystano dane $z$ lat 1978-1999 (MARSZ i STYSZYŃSKA 2000), z 2012 r. (KEJNA i współaut. 2013a) oraz $z$ lat 2013-2020. Pomiary meteorologiczne na Stacji Arctowski sa prowadzone od początku jej działalności. W latach 19772001 wykonywano je w sposób tradycyjny w ogródku meteorologicznym. Niestety w latach 2001-2012 pomiary byly wykonywane nieregularnie, a więc brakuje kompletnych danych $z$ tego okresu. Od końca 2012 r. działa automatyczna stacja meteorologiczna. Szczegółowa charakterystyka metodyki pomiarów została opisana $\mathrm{w}$ artykule PLENZLER i współaut. (2019).

Analiza porównawcza danych $z$ lat 19781999 i 2012-2020 (Ryc. 19), potwierdza za-

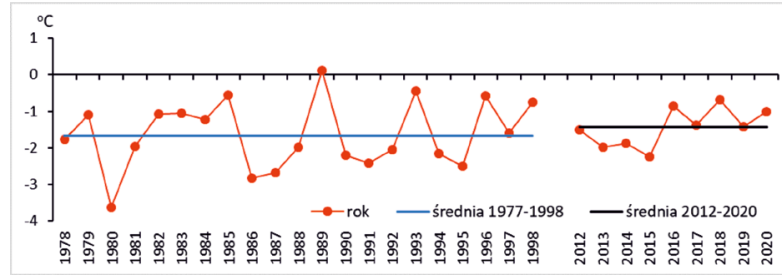

Ryc. 19. Przebieg średniej rocznej temperatury powietrza na Stacji Arctowskiego w latach 19781998 i 2012-2020 na tle wieloleci 1978-1998 oraz 2012-2020. 


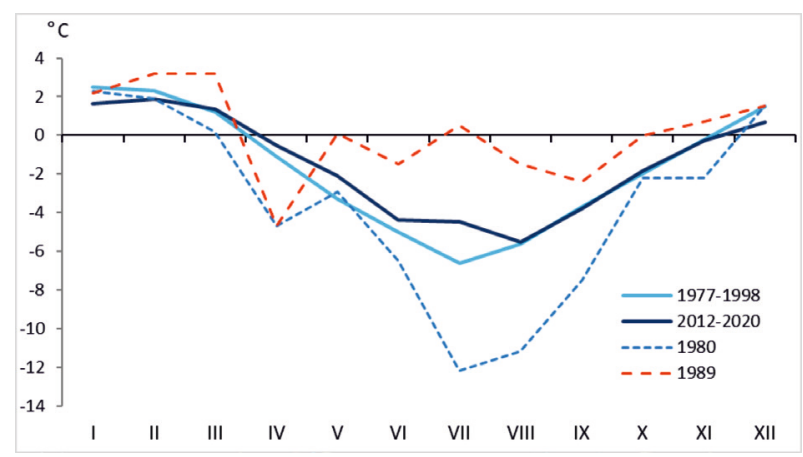

Ryc. 20. Uśredniony przebieg roczny średniej miesięcznej temperatury powietrza na Stacji Arctowskiego w wieloleciach 1978-1998 i 2012-2020 oraz roku najchłodniejszym 1980 i najcieplejszym 1989.

obserwowane już wcześniej na Wyspie Króla Jerzego ocieplenie (KEJNA i współaut. 2013 a). Stwierdzono przy tym większy wzrost temperatury powietrza $\mathrm{w}$ miesiacach zimowych względem letnich oraz wzrost temperatury minimalnej. Mimo znacznej zmienności $z$ roku na rok wyraźnie widać postępujace ocieplenie. Średnia roczna temperatura w latach 2012-2020 wyniosła $-1,4^{\circ} \mathrm{C}$, tj. była o $0,3^{\circ} \mathrm{C}$ wyższa w porównaniu do lat 1978 $1998\left(-1,7^{\circ} \mathrm{C}\right)$. Ocieplenie dotyczyło przede wszystkim miesięcy jesiennych i zimowych, tj. od kwietnia do lipca. Różnica w latach 2012-2020 siegała od $0,6^{\circ} \mathrm{C}$ do $2,1^{\circ} \mathrm{C}$ w stosunku do 1978-1998. Najbardziej zmieniła się średnia miesięczna temperatura lipca. Lipiec był również średnio najzimniejszym miesiącem w pierwszym okresie pomiarowym, natomiast $\mathrm{w}$ ostatnich dziewiecciu latach był to sierpień. Miesiace letnie (grudzień-luty), uległy nieznacznemu ochłodzeniu względem lat 1978-1998 (Ryc. 20). Nie zmieniła się średnia miesięczna temperatura od sierpnia do listopada oraz marca.

W ostatnich latach ocieplenie przejawia się również dużo wyższymi temperaturami minimalnymi. Latach 1978-1998 absolut-

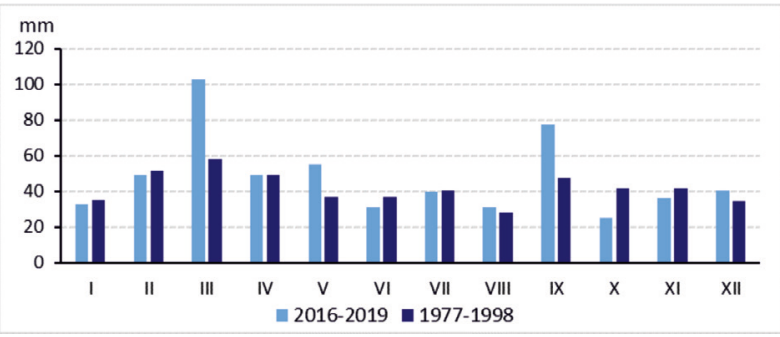

Ryc. 21. Roczny przebieg miesięcznych wartości opadu atmosferycznego na Stacji im. Arctowskiego w latach 2016-2019 i 1977-1998. ne roczne temperatury minimalne wynosiły od $-15,1^{\circ} \mathrm{C}$ do $-32,3^{\circ} \mathrm{C}$, natomiast w latach 2012-2020 od $-17,2^{\circ} \mathrm{C}$ do $-22,6^{\circ} \mathrm{C}$. Podobnych prawidłowości nie wykazuja temperatury maksymalne.

Na Wyspie Króla Jerzego średnia roczna suma opadów w okresie 2016-2019 wyniosła $570 \mathrm{~mm}$ i była porównywalna do wartości z okresu 1977-1998 (MARSZ i STYSZYŃSKA 2000). Najwyższe sumy opadów w przebiegu rocznym notuje się $\mathrm{w}$ marcu i wrześniu (Ryc. 21). Liczba dni $z$ pokrywą śnieżną na podstawie obserwacji $z$ lat 2016-2019 utrzymuje się średnio przez około 180 dni w roku. Największe miąższości pokrywy śnieżnej obserwuje się w miesiacach od czerwca do sierpnia, pokrywa śnieżna może miejscami osiągnąć do $150 \mathrm{~cm}$ grubości.

\section{WPEYW ZMIAN KLIMATU NA EKOSYSTEMY W ANTARKTYCE}

Skutki zmian klimatu w Antarktyce sa najbardziej widoczne w rejonie Półwyspu Antarktycznego. Badania prowadzone na Wyspie Króla Jerzego wykazały szybka deglacjację tego obszaru, przejawiajacca się wycofywaniem się czół lodowców oraz zmiany ich miąższości (SIMÕEs i współaut. 1999, COOK i współaut. 2005, RÜCKAMP i współaut. 2011, DAVIES i współaut. 2012, FIEBER i współaut. 2018). Uwzględniając fakt, że suma opadów na Wyspie Króla Jerzego nie zmienia się znacząco (KEJNA i współaut. 2013b), wzrost temperatury powietrza i częstsze występowa-

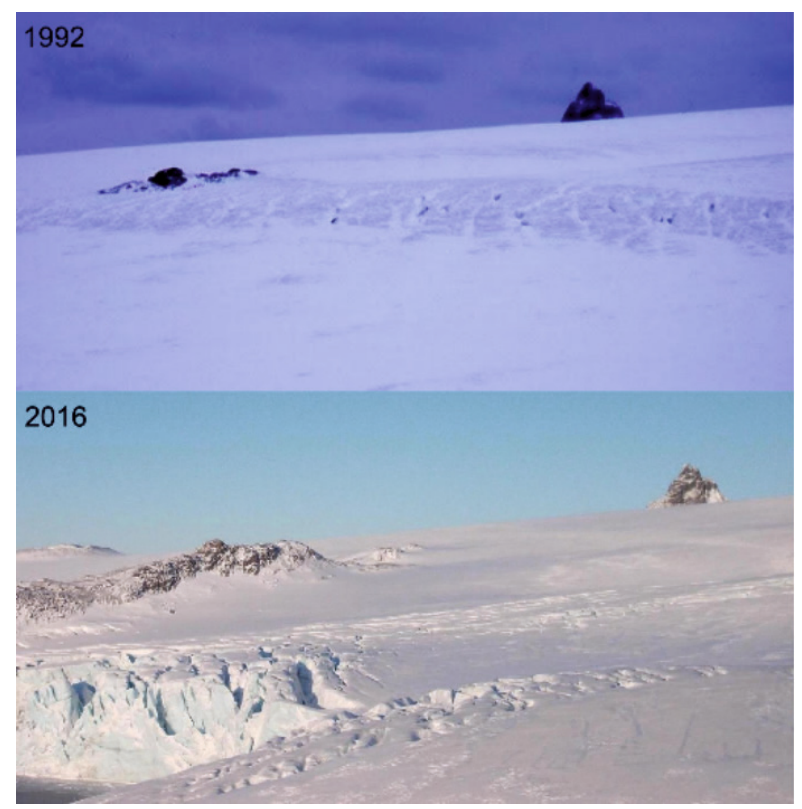

Ryc. 22. Lodowiec Ekologii w roku 1992 i 2016 (fot. J. Terakowski - 1992, J. Plenzler - 2016). Objaśnienie: Czoło Lodowca Ekologii od 1979 r. cofnęło się o ponad $600 \mathrm{~m}$. 
nie dodatnich jej wartości sprzyjaja topnieniu śniegu i lodowców (PUDEEKO i współaut. 2018).

Uwalnianie od lodu powierzchni gruntu sprzyja dalszemu ociepleniu, ponieważ absorbuje on więcej promieniowania słonecznego niż lód (dodatnie sprzężenie zwrotne). Skały i grunt oddaja zmagazynowane ciepło powodujac wzrost temperatury oraz przyspieszając topnienie lodowców (JANIA 1997). Zjawisko to jest szczególnie widoczne przy nunatakach (szczyt wznoszacy się nad powierzchnię ladolodu), np. od 1979 r. do 2018 r. powierzchnia lodu przy nunatakach Siodło i Tarnica obniżyła się od 15 do 30 $\mathrm{m}$, powodując że połączyły się one ze stałym lądem (PUDEŁKo i współaut. 2018) (Ryc. 22).

Czoło położonego najbliżej Polskiej Stacji Antarktycznej Lodowca Ekologii od 1978 r. do 2016 r. cofnęło się o ok. $600 \mathrm{~m}$, a wysokość powierzchni lodowca obniżyła się średnio o $58 \mathrm{~m}$ (PĘTLICKI i współaut. 2017). Łaczna powierzchnia położonych obok siebie lodowców Ekologia i Sphinx w latach 1979-2012 zmniejszyła się o 41\% (SовоTA i współaut. 2015). W latach 1979-2018 lodowce położone na zachodnim brzegu Zatoki Admiralicji, w obrębie obszaru chronionego ASPA 128 (Antarctic Specially Protected Area), cofając się odsłoniły $6,2 \mathrm{~km}^{2}$ terenu. Najszybsze tempo ubytku masy lodowców zostało zaobserwowane podczas dwóch ostatnich dekad XX w. (KEJNA i współaut. 1998, BRAUN i współaut. 2001, BLINDOW i współaut. 2010, RÜCKAMP i współaut. 2011, QUARTINO i współaut. 2013, SIMÕES i współaut. 2015, SовотA i współaut. 2015, PETLICKI i współaut. 2017, JEROSCH i współaut. 2018, PUDEŁKO i współaut. 2018, SZIEO i BIALIK 2018, PASIK i współaut. 2021).

Wycofywanie się lodowców uchodzacych do morza prowadzi do powstania lub powiększenia lagun i zatok. Takie zatoki powstały m.in. przed czołami lodowców Fourcade, Vievielle, Lange, Zalewski, Baranowski, Ekologia, Dera (RÜCKAMP i współaut. 2011, QUARTINO i współaut. 2013, SZIŁO i BIALIK 2018, РотосKA i współaut. 2019, OsińSKA i współaut. 2021). Powierzchnia laguny przed lodowcem Ekologii w 2016 r. wynosiła 0.3 $\mathrm{km}^{2}$ (SZIŁO i BIALIK 2018), podczas gdy $\mathrm{w}$ 1979 r. obszar ten był jeszcze niemal całkowicie przykryty lodem. Od 1958 r. przed lodowcem Vievielle powstała laguna o powierzchni ok. $1 \mathrm{~km}^{2}$ i maksymalnej głębokości 48,3 m (OsińSKA i współaut. 2021). Na obszarach morenowych przed lodowcami powstały liczne jeziorka (m.in. Jeziorko Imbirowe, Górne i Błotniste położne w południowej części obszaru ASPA 128) (PUDEŁKo 2002) oraz formuja się nowe strumienie (SzIEO i BIALIK 2017, 2018; SZOPIŃSKA i współaut.
2018). Odsłoniety przez ustepujace lodowce ląd i dno morskie tworza nowa przestrzeń do zasiedlania przez organizmy żywe. Na osłoniętym w latach 1993-2009 przez lodospad Dery obszarze zaobserwowano ekspansję gatunków zamieszkujących dno morskie (POTOCKa i współaut. 2019). W zatoce Potter Cove przed lodowcem Fourcade wykazano zasiedlanie dna przez makroalgi (QUARTINO i współaut. 2013). Na skutek ocieplenia występuje zwiększona dostawa słodkiej wody do morza, co wpływa na ekosystemy podwodne (QUARTINO i współaut. 2013, JEROSCH i współaut. 2018, РОтОсKA i współaut. 2019, BRAECKMAN i współaut. 2021). Wraz woda dostaja się do morza osady powodujące zwiększenie mętności wody w obszarach przybrzeżnych (OsIŃSKA i współaut. 2021). $\mathrm{Na}$ odsłoniętym obszarze lądowym następuje stopniowa sukcesja mchów, porostów i roślin naczyniowych (OLECH i współaut. 2011).

W ostatnich dekadach na Wyspie zaobserwowano znaczne zmiany $\mathrm{w}$ populacjach gniazdujacych tam pingwinów. Zmniejszyła się populacja pingwinów białookich i maskowych, natomiast zwiększyła sie populacja pingwinów białobrewych. Powoduja to m.in. zmiany $\mathrm{w}$ zasięgu lodu morskiego, które determinuja dostępność pokarmu, w szczególności kryla (HINKE i współaut. 2007, 2014; TRIVELPIECE i współaut. 2011). Zmiany klimatu moga prowadzić do ekspansji w kierunku południowym i prób kolonizacji coraz cieplejszych rejonów przez gatunki żyjące w rejonie subantarktycznym (min. Georgia Pd., Ziemia Ognista, Falklandy Pd.). Na Szetlandach Pd. zaobserwowano już trzy miejsca, w których pingwiny królewskie podejmuja próby lęgu. Jedno $z$ nich znajduje się $\mathrm{w}$ rejonie przyląka Lions Rump na Wyspie Króla Jerzego (GRYZ i współaut. 2018). Częstsze pojawianie się i dłuższe pozostawanie na Szetlandach Południowych biegusa białorzytnego (będacego gatunkiem zalatującym w tym rejonie) również jest zwiazane $z$ ociepleniem klimatu (KORCZAK-ABSHIRE i współaut. 2011). Wymienione przykłady jedynie zarysowuja skalę wpływu zmian klimatu na ekosystemy lądowe i morskie Wyspy Króla Jerzego.

Zmiany klimatu w Arktyce i Antarktyce wywołują złożone skutki środowiskowe, społeczne i gospodarcze, wykraczajace poza regiony polarne. Zespół IPCC opracował w 2021 r. interaktywny atlas, który umożliwia dostęp do aktualnych informacji na temat zmian klimatu $\mathrm{w}$ różnych regionach $\mathrm{m}$.in. $\mathrm{w}$ Arktyce i Antarktyce. Jest on dostępny na stronie IPCC https://interactive-atlas.ipcc. $\mathrm{ch} /$.

\section{Streszczenie}

Obecnie obserwowane sa znaczne zmiany klimatu w Arktyce i Antarktyce. Wzrost średniej temperatury po- 
wietrza w Arktyce w latach 1979-2019 był trzykrotnie wyższy niż średnia globalna. W Antarktyce największe ocieplenie występuje w rejonie Półwyspu Antarktycznego. Polska również uczestniczy w monitorowaniu warunków pogodowych w Arktyce na południowym Spitsbergenie w Stacji im. S. Siedleckiego w Hornsundzie oraz w Antarktyce w Stacji im. H. Arctowskiego na wyspie Króla Jerzego. Zmiany klimatu w polarnych ekosystemach powoduja występowanie różnych zagrożeń m.in. topnienie lodowców i pokrywy morskiej, wieloletniej zmarzliny i pokrywy śnieżniej. Zmienia się skład gatunkowy flory i fauny obszarów polarnych.

\section{LITERATURA}

Alexeev V. A., Walsh J. E., Ivanov V. V., SeMENOV V. A., SMIRNOV A. V., 2017. Warming in the Nordic seas, North Atlantic storms and thinning Arctic sea ice. Environ. Res. Lett. 12, doi.org/10.1088/1748-9326/aa7a1d.

AMAP, 2017. Snow, Water, Ice and Permafrost. Summary for Policy-makers. Arctic Monitoring and Assessment Programme (AMAP), Oslo, Norway.

AMAP, 2021. Arctic Climate Change Update 2021: Key Trends and Impacts. Summary for Policy-makers. Arctic Monitoring and Assessment Programme (AMAP), Tromsø, Norway.

ANGHILERI D., PIANOSI F., SONCINI-SESSA R., 2014. Trend detection in seasonal data: from hydrology to water resources. J. Hydrol. 511, 171179.

ARAŽNY A., 2008. Bioklimat Arktyki Norweskiej $i$ jego zmienność $w$ okresie 1971-2000. Wyd. Uniwersytetu Mikołaja Kopernika w Toruniu.

ARAŹNY A., 2019. Temporal and spatial variability of thermal and humidity stimuli in the Hornsund area (Svalbard). Pol. Polar Res. 40, 2953.

BLINDOW N., SCUKRO S., RÜCKAMP M., BRAUN M., SCHINDLER M., BREUER B., SAURER H., SiMOES J.C., LANGE M., 2010. Geometry and status of the King George Island Ice cup (South Shetland Island, Antarctica). Ann. Glaciol. 51, 103-109.

BŁASZCZYK M., JANIA J. A., KOLONDRA L., 2013. Fluctuations of tidewater glaciers in Hornsund Fiord (Southern Svalbard) since the beginning of the 20th century. Pol. Polar Res. 34, 327352.

BobyleV L. P., KondRATYEV K. YA., JOHANNESSEN O. M., 2003. Arctic Environment Variability in the Context of Global Change. Praxis Publishing, Chichester.

BraECKMAN U., PASOTTi F., HOFFMANN R., VÁZQUeZ S., A. WULFF , SchlOSS I. R., FALK U., DEREgiBUS D., LEFAIBLE N., TORSTENSSON A., Al-Handal A., WenZhöFer F., VANREUSEl A., 2021. Glacial melt disturbance shifts community metabolism of an Antarctic seafloor ecosystem from net autotrophy to heterotrophy. Comm. Biol. 4, doi: 10.1038/s42003-02101673-6.

Braun M., Simoes J. C., Vogt S., Bremer U. F., Blindow N., PFEnder M., SAURER H., AQUiNO F. E., FERRON F. A., 2001. An improved topographic database for King George: compilation, application and outlook. Antarctic Sci. 13, 4152 .

BROMWICH D. H., 1990. Estimates of Antarctic precipitation. Nature 343, 627-695.

BRomwich D. H., GUO Z. C., BAI L. S., CHEN Q. S., 2004. Modeled Antarctic precipitation. Part
I: spatial and temporal variability. J. Climate $17,427-447$.

Bromwich D. H., Nicolas J. P., Monaghan A. J., 2011. An assessment of precipitation changes over Antarctica and the Southern Ocean since 1989 in contemporary global reanalyses. J. Climate 24, 4189-4209.

Buchwat A., Sullivan P. F., Macias-Fauria M., Post E., Myers-Smith I. H., STROEVE J.C., BlOK, D., TAPE, K.D., FORBES, B.C., ROPARS, P., LÉVESQUEN, E. i współaut. 2020. Divergence of Arctic shrub growth associated with sea ice decline. Proc. Natl. Acad. Sci. USA 117, 33334-33344.

CAFF, 2013. Arctic Biodiversity Assessment. Report for Policy Makers. Conservation of Arctic Flora and Fauna (CAFF), Akureyri, Iceland, www.arcticbidiversity.is.

CARR J. R., STOKES C. R., VIELI A., 2017. Threefold increase in marine-terminating outlet glacier retreat rates across the Atlantic Arctic: 1992-2010. Ann. Glaciol. 58, doi: 10.1017/ aog. 2017.3

CARRASCO J. F., 2013. Decadal changes in the near-surface air temperature in the western side of the Antarctic Peninsula. Atmosphere. Clim. Sci. 3, 275-281.

COOK A. J., FOX A. J., VAughan D. G., FERringo J. G., 2005. Retreating glacier fronts on the Antarctic Peninsula over the past half-century. Science 308, 541-544.

Comiso J., 2012. Large decadal decline of the Arctic multiyear ice cover. J. Clim. 25, 11761193.

DAVIES B. J., CARRIVICK J. L., Glasser N. F., HAMBREY M. J., SMElliE J.' L., 2012. Variable glacier response to atmospheric warming, northern Antarctic Peninsula, 1988-2009. Cryosphere 6, 1031-1048.

Descamps S., Aars J., Fuglei E., Kovacs K. M., Lydersen C., Pavlova O., Pedersen Å., RaVOLAINEN V., STRØM H., 2017. Climate change impacts on wildlife in a High Arctic archipelago - Svalbard Norway. Glob. Chang. Biol. 23, 490-502.

Fieber K. D., Mills J. P., Miller P. E., Clarke L., IRELAND L., FOX A. J., 2018. Rigorous 3D change determination in Antarctic Peninsula glaciers from stereo WorldView-2 and archival aerial imagery. Remote Sensing Environ. 205, 18-31.

Førland E. J., HANSSEn-BAuER I., 2003. Climate variations and implications for precipitation types in the Norwegian Arctic. Norwegian Meteorological Institute, Report no. 24/02 KLIMA.

GryZ P., Gerlée A., KorCZAK-ABShire M., 2018. New breeding site and records of king penguins (Aptenodytes patagonicus) on King George Island (South Shetlands, Western Antarctic). Polar Rec. 54, 275-283.

Guarino M. V., Sime L. C., SchröEder D. i wspólaut., 2020. Sea-ice-free Arctic during the Last Interglacial supports fast future loss. Nat. Clim. Chang. 10, 928-932.

HAMED K. H., RAO A. R., 1998. A modified Mann-Kendall trend test for autocorrelated data. J. Hydrol. 204, 182-196.

HANSSEN-BAUER I., FøRlAND E. J., 1998. Long-term trends in precipitation and pemperature in the Norwegian Arctic: Can they be explained by changes in atmospheric circulation patterns? Clim. Res. 10, 143-153.

Hinke J. T., SAlWICKA K., TRIVELPIECE S. G., WATTERS G. M., TRIVELPIECE W. Z., 2007. Divergent responses of Pygoscelis penguins reveal 
a common environmental driver. Oecologia153, 845-855.

Hinke J. T., TRIVElPiece S. G., TRivelpiece W. Z., 2014. Adélie penguin (Pygoscelis adeliae) survival rates and their relationship to environmental indices in the South Shetland Islands, Antarctica. Polar Biol. 37, 1797-1809.

IPCC, 2021. Climate Change 2021: The Physical Science Basis. Contribution of Working Group I to the Sixth Assessment Report of the Intergovernmental Panel on Climate Change. Cambridge Univ. Press. https://www.ipcc.ch/ report/ar6/wg1/downloads/report/IPCC_AR6_ WGI_Full_Report.pdf.

JACKA T. H., BUDD W. $\overline{\mathrm{F}} ., 1998$. Detection of temperature and sea-ice-extent changes in the Antarctic and Southern Ocean, 1949-1996. Ann. Glaciol. 27, 553-559.

JANIA J., 1997. Glacjologia. Wydawnictwo Naukowe PWN, Warszawa.

Jerosch K., Pehlke H., Monien P., Scharf F., Weber L., KuhN G., BRAUN M. H., ABELE D., 2018. Benthic meltwater fjord habitats formed by rapid glacier recession on George Island, Antarctica. Philosoph. Transact. Royal Soc. A 376, https://doi.org/10.1098/rsta.2017.0178.

JONES P. D., 1995. Recent variations in mean temperature and the diurnal temperature range in the Antarctic. Geophys. Res. Lett. $22,1345-1348$.

Jung O., Sung M.-K., SATO K., Lim Y.-K., KIM S.J., BAEK E.-H., JEONG J.-H., KIM B.-M., 2017. How does the SST variability over the western North Atlantic Ocean control Arctic warming over the Barents-Kara seas? Environ. Res. Lett. 12, doi.org/10.1088/1748-9326/aa5f3b.

KatTsov V. M., WALSH J. E., CHAPMAN W. L., Govorkova V. A., PAVlova T. V., Zhang X., 2007. Simulation and projection of Arctic freshwater budget components by the IPCC AR4 global climate models. J. Climate 8, 571-589.

KEJNA M., 1999. Air temperature on King George Island, South Shetland Islands, Antarctica. Pol. Polar Res. 20, 183-201.

KEJNA M., 2003. Trends of air temperature of the Antarctic during the period 1958-2000. Pol. Polar Res., 24, 99-126.

KEJNA M., 2008. Rozkład przestrzenny $i$ zmiany temperatury powietrza na Antarktydzie $w$ drugiej połowie XX wieku. Wyd. Uniwersytetu Mikołaja Kopernika w Toruniu.

KEJNA M., LASKA K., CAPUTA Z., 1998. Recession of Ecology Glacier (King George Island) in the period 1961-1996. 25th International Polar Symposium, Warsaw, Pol. Polar Stud. 121128.

KEJNA M., ARAŹNy A., Sobota I., 2013a. Climatic change on King George Island in the years 1948-2011. Pol. Polar Res. 34, 213-235.

KEJNA M., ARAŹNY A., SOBOTA I., PISZCZEK J., ŁABNO R., 2013b. Meteorological conditions at the Arctowski Station (King George Island, Antarctic) in 2012. Probl. Klimat. Polar. 23, 43-56.

Kendall M. G., 1975. Rank Correlation Methods. Charles Griffin, London.

Khon V. C., MOKHOV I. I., Roeckner E., Semenov V. A., 2007. Regional changes of precipitation characteristics in Northern Eurasia from simulations with global climate model. Global Planet Change 57, 118-123.

KING J. C., TURNER J., 1997. Antarctic meteorology and climatology. Cambridge University Press.

KOHNEMANN S. H. E., HEINEMANN G., BROMWICH D., GUTJAHR O., 2017. Extreme warming in the Kara Sea and Barents Sea during the winter period 2000-16. J. Clim. 30, 89138927.

KORCZAK-ABSHIRE M., ANGIEL P. J., WIERZBICKI G., 2011. Records of white-rumped sandpiper (Calidris fuscicollis) on the South Shetland Islands. Polar Rec. 47, 262-267.

Lazzara M. A., Weidner G. A., Keller L. M., THOM J. E., CASSANO J. J., 2012. Antarctic automatic weather station program: 30 years of polar observation. Bull. Amer. Meteor. Soc. 93, 1519-1537.

MANN H., 1945. Nonparametric tests against trend. Econometrica 13, 245-259,

MARSZ A. A., STYSZYŃSKA A., 2000. Główne cechy klimatu rejonu Polskiej Stacji Antarktycznej im. H. Arctowskiego (Antarktyka Zachodnia, Szetlandy Południowe, Wyspa Króla Jerzego). Wyższa Szkoła Morska w Gdyni, Gdynia.

MARSZ A. A., STYSZYŃSKA A., 2013. Climate and Climate change at Hornsund, Svalbard. Gdynia Maritime University, Gdynia, Poland.

Mayewski P. A., Meredith M. P., Summerhayes C. P., Turner J., WORBY A., BARRETT P. J., CASASSA G., Bertler N. A. N. i współaut., 2009. State of the Antarctic and Southern Ocean Climate System. Rev. Geophys. 47, doi.org/10.1029/2007RG000231.

McBean G., Alekseev G., Chen D., Førland E., Fyfe J., Groisman P. Y., King R., Melling H., Vose R., WhitFIELD P. H., 2005. Arctic climate - past and present. [W:] Arctic Climate Impact Assessment. Cambridge University Press, 2160.

McAfee S. A., Guentchev G., Eischeid J. K. 2013. Reconciling precipitation trends in Alaska: 1. Station based analyses. J. Geophys. Res. Atmos. 118, 7523-7541.

McAFEe S., GuentcheV G., EISCHEID J., 2014. Reconciling precipitation trends in Alaska: 2. Gridded data analyses. J. Geophys. Res. Atmos. 119, 13820-13837.

MONAGHAN A. J., BROMWICH D. H., FOGT R. L., WANG S.-H., MAYEWSKI P. A., DIXON D.A., EKAYKIN A., FREZZOTTI M., GoODWIN I. i wspó1aut., 2006. Insignificant change in Antarctic snowfall since the International Geophysical Year. Science 313, 827-831.

Mulvaney R., ABRAM N., HindmaRsh R. i współaut., 2012. Recent Antarctic Peninsula warming relative to Holocene climate and ice-shelf history. Nature 489, 141-144.

NoAA, 2021. National Centers for Environmental information, Climate at a Glance, Global Time Series. https://www.ncdc.noaa.gov/cag/, dostep: 21.09.2021.

Olech M., WegrzyN M., LisowsKa M., SŁaBY A., ANGIEL P., 2011, Contenporary changes in vegatation of polar regions. Pap. Global Change 18, 35-51.

Olech M., Węgrzyn M., Lisowska M., ChWedoRZEWSKA K. J., SŁABY A., 2013. Polarne ekosystemy $w$ kontekście zmian klimatycznych. Kosmos 62, 365-372.

Oliva M., NAVARRO F., HRBÁČEK F., HERNÁNDEZ A., NYYVlT D., PEREIRA P., 2016. Recent regional climate cooling on the Antarctic Peninsula and associated impacts on the cryosphere. Sci. Total Environ. 580, 210-223.

OSIŃSKA M., BIALIK R. J., WÓJCIK-DŁUGOBORSKA K., 2021. Interrelation of quality parameters of surface waters in five tidewater glacier coves of King George Island, Antarctica. Sci. Total Environ. 771, 1doi.org/10.1016/j.scitotenv.2020.144780.

OSUCH M., WAWRZYNIAK T., 2017. Inter- and intra-annual changes of air temperature and preci- 
pitation in western Spitsbergen. Int. J. Climatol. 37, 3082-3097,

Quartino M. L., Deregibus D., Campana G. L., LATORRE G. E. J., MOMO F. R., 2013. Evidence of Macroalgal Colonization on Newly Ice-Free Areas following Glacial Retreat in Potter Cove (South Shetland Islands), Antarctica. PLoS One 8, doi: 10.1371/journal. pone.0058223.

PASIK M., BAKUŁA K., RÓZYCKI S., OSTROWSKI W., KOWALSKA M. E., FIJAEKOWSKA A., RAJNER M., ŁAPINSKI S., SOBOTA I., KEJNA M., OSIŃSKA-SOTAK K., 2021. Glacier geometry changes in the western shore of Admiralty Bay, King George Island over the last decades. Sensors 21, doi: $10.3390 / \mathrm{s} 21041532$.

Pętlicki M., SziŁo J., Macdonell S., Vivero S., BIALIK R. J., 2017. Recent Deceleration of the ice elevation change of Ecology Glacier (King George Island, Antarctica). Remote Sensing 9, doi:10.3390/rs9060520.

Post E., Alley R. B., Christensen T. R., MaciasFAuria M., Forbes B. C., GoOsefF M. N., IleR A., KeRBY J. T., LAIDRE K. L. i współaut., 2019. The polar regions in a $2{ }^{\circ} \mathrm{C}$ warmer world. Science Adv. 5, doi.org/10.1126/sciadv.aaw9883.

Potocka M., Kidawa A., Panasiuk A., Bielecka L., WAWRZYNEK-BOREJKO J., PATUŁA W., WÓJCIK K. A., Plenzler J., Janecki T., BialiK R. J., 2019. The effect of glacier recession on benthic and pelagic communities: case study in Herve Cove, Antarctica. J. Mar. Sci. Eng. 7, doi.org/10.3390/jmse7090285.

PlenzleR J., BudZIK T., PUCZKO D., BialiK R. J., 2019. Climatic conditions at the $H$. Arctowski Polish Antarctic Station (King George Island, Antarctica) in 2013-2017 against the background of observed regional changes. Pol. Polar Res. 40, 1-27.

PRevidi M., Smith K. L., Polvani L. M., 2021. Arctic amplification of climate change: a review of underlying mechanisms. Environ. Res. Lett. 16, doi.org/10.1088/1748-9326/ac1c29.

PRZYBYLAK R., 2002. Variability of Air Temperature and Atmospheric Precipitation in the Arctic. Atmospheric and Oceanographic Sciences Library 25, Kluwer Academic Publishers, Dordrecht/Boston/London.

PRZYBYLAK R., 2007a. Współczesne zmiany klimatu $w$ Arktyce. [W:] Zmiany klimatyczne w Arktyce $i$ Antarktyce $w$ ostatnim piećdziesiecioleciu $X X$ wieku $i$ ich implikacje środowiskowe. STYSZYŃSKA A. MARSZ A. A. (red.). Akademia Morska, Gdynia, 93-110.

PRZYBYLAK R., 2007b. Recent air-temperature changes in the Arctic. Ann. Glaciol. 46, 316324.

PRZYBYLAK R., 2016. The Climate of the Arctic. Atmospheric and Oceanographic Sciences Library 52, Kluwer Academic Publishers, Dordrecht/Boston/London.

PRZYBYLAK R., WYSZYŃSKI P., 2020. Air temperature changes in the Arctic in the period 19512015 in the light of observational and reanalysis data. Theor. Appl. Climatol. 139, 75-94.

PudEŁKo R., 2002. Site of Special Scientific Interest No. 8, King George Island, 1:12 500. Department of Antarctic Biology, Warsaw.

PudęKo R., ANGIEl J. P., POTOCKI M., JęDREJEK A., KOZAK M., 2018. Fluctuation of glacial retreat rates in the eastern part of Warszawa Icefield, King George Island, Antarctica, 19792018. Remote Sensing 10, doi.org/10.3390/ rs 10060892 .
RAPER S. C. B., Wigley P. R., MAYES P. R., JONES P. D., SALINGER M. J., 1984. Variations in surface air temperatures. Part 3: The Antarctic, 1957-1982. Mon. Weath. Rev., 112, $1341-1353$

Regehr E. V., LAidRe K. L., AKÇAKaya H. R., AmSTRUP S. C., ATWOOD T. C., LUNN N. J., OBBARD M., Stern H., ThiemanN G. W., WiIG Ø., 2016. Conservation status of polar bears (Ursus maritimus) in relation to projected sea-ice declines. Biol. Lett. 12, doi:10.1098/ rsbl.2016.0556.

RÜCKAMP M., BRAUn M., SUCKRO S., AND Blindow N., 2011. Observed glacial changes on the King George Island ice cap, Antarctica in the last decade. Global Planet. Change 79, 99109.

SEN P. K., 1968. Estimates of the regression coefficient based on Kendall's tau. J. Am. Stat. Assoc. 63, 1379-1389.

SERREZE M. C., BARRETT A. P., LO F., 2005. Northern high-latitude precipitation as depicted by atmospheric reanalyses and satellite retrievals. Mon. Wea. Rev. 133, 3407-3430.

SERREZE M. C., BARRY R. G., 2011. Processes and impacts of arctic amplification: $A$ research synthesis. Glob. Planet. Change 77, 85-96.

SIMÕES J., BREMER U. F., AQUINO F .E., FERRON F. A., 1999. Morphology and variation of glacial drainage basins in the King George Island ice filed, Antarctica. Ann. Glaciol. 29, 220224.

SimÕes C. L., Da Rosa K. K., Czapela F. F., VieiRA R. AND SIMÕES J. C., 2015. Collins Glacier retreat process and regional climatic variations, King George Island, Antarctica. Geograph. Rev. 105, 462-471.

SimMONDS I., KEAY K., LIM E. P. 2003. Synoptic activity in the seas around Antarctica. Mon. Weather Rev. 131, 272-288.

SoвоTA I., 2013. Współczesne zmiany kriosfery pótnocno-zachodniego Spitsbergenu na przykładzie rejonu Kaffiøyry. Wyd. Naukowe UMK, Toruń.

Sobota I., KeJnA M., ARAŹNY A., 2015. Short-term mass changes and retreat of the Ecology and Sphinx glacier system, King George Island, Antarctic Peninsula. Antarctic Sci. 27, 500510.

StammerJohn S. E., MARTINSON D. G., SMith R. C., IANNUZZI R. A., 2008. Sea ice in the western Antarctic Peninsula region: Spatio-temporal variability from ecological and climate change perspectives. Deep Sea Research Part II: Topical Studies in Oceanography 55, 2041-2058.

STASTNA V., 2010. Spatio-temporal changes in surface air temperature in the region of the northern Antarctic Peninsula and south Shetland islands during 1950-2003. Polar Sci. 4, 18-33.

SzIŁO J., BIALIK R. J., 2017. Bedload transport in two creeks at the ice-free area of the Baranowski Glacier, King George Island, West Antarctica. Pol. Polar Res. 38, 21-39.

SZILO J., BIALIK R. J., 2018. Recession and Ice Surface Elevation Changes of Baranowski Glacier and its impact on proglacial relief (King George Island, West Antarctica). Geosciences 8, doi.org/10.3390/geosciences8100355.

SZOPIŃSKA M., SZUMIŃSKA D., BIALIK R.J., CHMIEL S., Plenzler J., Polkowska Ż., 2018. Impact of a newly-formed periglacial environment and other factors on fresh water chemistry at the western shore of Admiralty Bay in the summer of 2016 (King George Island, Maritime Antarctica). Sci. Total Environ. 613-614, 619-634. 
TANG M. S. Y., Chenoli S. N., COlwell S., GRANT R., SimMS M., LAW J., SAMAH A. A., 2018, Precipitation instruments at Rothera Station, Antarctic Peninsula: a comparative study. Polar Res. 37, doi: 10.1080/17518369.2018.1503906.

TREshnikov A. F., 1985. Atlas Arktiki. Arctic and Antarctic Research Institute, Moscow.

Trivelpiece W. Z., Hinke J. T., Miller A. K., REiss C. S., TRIVElPiece S. G., WatTers G. M., 2011. Variability in krill biomass links harvesting and climate warming to penguin population changes in Antarctica. Proc. Natl. Acad. Sci. USA 108, 7625-7628.

TURNER J., MARShall G. J., 2011. Climate Change in the Polar Regions. Cambridge: Cambridge University Press.

TURner J., COlwell S. R., MARShall J. G., LACHlan-Cope T. A., CaRleton A. M., Jones P. D., LAGUN V., REID P. A., IAGOVKINA S., 2004. The SCAR READER Project: Toward a High-Quality Database of Mean Antarctic Meteorological Observations. J. Clim. 17, doi.org/10.1175/1520 -0442(2004)017<2890:TSRPTA>2.0.CO;2.

TURNer J., COLWEll S. R., MARShall G. J., LACHLAN-COPA T. A., CARLETON A. M., JONES P. D., LAgun V., REID P. A., IAgOVkina S., 2005. Antarctic climate change during the last 50 years. Int. J. Climatol. 25, 279-294.

TURNER J., BARRAND N. E., BRACEGIRDLE T. J., CONVEY P., HODGSON D. A., JARVIS M., JENKINS A., MARShall G., MEREdiTh M. P., RoSCOE H, SHANKLIN J., 2013a. Antarctic climate change and the environment: an update Polar Rec. 50, doi:10.1017/S0032247413000296 1.

TURNer J., MAKSYM T., PHILlips T., Marshall G. J., MEREDIT M. P., 2013b. Impact of changes in sea ice advance on the large winter warming on the western Antarctic Peninsula. Int. J. Climatol. 33, 852-861.

TURner J., Lu H., White I., KING J. C., PHILliPS T., Hosking J. S., BRACEgIRdLE T. J., MARShall G. J., Mulvaney R., DeB P., 2016. Absence of 21 st century warming on Antarctic Peninsula consistent with natural variability. Nature 535, 411-423.

Turner J., Marshall G. J. Clem K., Colwell S., PHILliPS T., LU H., 2019. Antarctic temperature variability and change from station data. Int. J. Climatol. 40, 2986-3007.

Turner J., LU H., King J., Marshall G.J. PhILLIPS T., BANNISTER D., COLWELl S., 2021. Ex- treme temperatures in the Antarctic. J. Clim. 34, 2653-2668.

VIHMA T., SCREEN J., TJERNSTRÖM M., NEWTON B., Zhang X., Popova V., Deser C., Holland M., PROWSE T., 2016. The atmospheric role in the Arctic water cycle: A review on processes, past and future changes, and their impacts. J. Geophys. Res. Biogeosci. 121, 586-620.

WALCZOWSKI W., PIECHURA J., 2011. Influence of the West Spitsbergen Current on the local climate. Int. J. Climatol. 31, 1088-1093.

Walsh J. E., Overland J. E., GROISMAN P. Y., RudolF B., 2011. Ongoing Climate Change in the Arctic. J. Human Environ. 40 (Supp1.), 6-16.

WAWRZYNIAK T., Osuch M., 2020. A 40-year High Arctic climatological dataset of the Polish Polar Station Hornsund (SW Spitsbergen, Svalbard). Earth Syst. Sci. Data 12, 805-815.

WAWRZYNIAK T., MAJERSKA M., OSUCH M., 2021. Hydrometeorological dataset (2014-2019) from the high Arctic unglaciated catchment Fuglebekken (Svalbard). Hydrol. Proc. 35, doi. org/10.1002/hyp.13974.

Wмо, 2017. Navigating Weather, Water, Ice and Climate Information for Safe Polar Mobilities. WWRP Polar Prediction Project No. 5, 2017, Geneva.

WMO, 2021. https://public.wmo.int/en/media/ press-release/wmo-verifies-one-temperaturerecord-antarctic-continent-and-rejects-another.

YU L., ZHONG S., 2021. Trends in Arctic seasonal and extreme precipitation in recent decades. Theor. Appl. Climatol. 145, 1541-1559.

Yurova A., Bobylev L. P., ZhU Y., DAVY R., KoRZHIKOV A. Y., 2018. Atmospheric heat advection in the Kara Sea region under main synoptic processes. Int. J. Climatol. 39, 361-374.

ZhU J., XIE A., QIN X., WANG Y., XU B., WANG Y., 2021. An Assessment of ERA5 Reanalysis for Antarctic Near-Surface Air Temperature. Atmosphere 12, doi.org/10.3390/atmos 12020217.

ZIAJA W., OSTAFIN K., 2019. Origin and location of new Arctic islands and straits due to glacial recession. Ambio 48, 25-34.

ZiAJA W., DUDEK J., LisOWSKA M., Olech M., OSTAFIN K., OSYCZKA P., WEGRZYN M., 2011. Transformation of the natural environment in Western Sørkapp Land (Spitsbergen) since the 1980s. Wyd. Uniwersytetu Jagiellońskiego, Kraków. 
KOSMOS Vol. 70, 4, 579-595, 2021

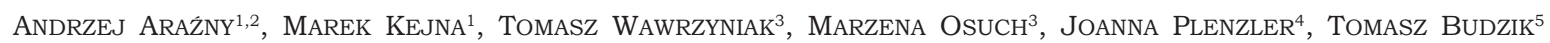

${ }^{1}$ Department of Meteorology and Climatology, Faculty of Earth Sciences and Spatial Management, Nicolaus Copernicus University in Toruń, 1 Lwowska Str., 87-100 Torun, ${ }^{2}$ Centre for Climate Change Research, 1 Lwowska Str., 87-100 Toruń, ${ }^{3}$ Institute of Geophysics PAS, 64 Księcia Janusza Str., 01-452 Warszawa, ${ }^{4}$ Department of Antarctic Biology, Institute of Biochemistry and Biophysics PAS, $5 a$ Pawińskiego Str., 02-106 Warszawa, ${ }^{5}$ Department of Climatology, Faculty of Earth Sciences, University of Silesia, 60 Będzińska Str., 41-200 Sosnowiec, E-mail: andy@umk.pl

\title{
CLIMATE CHANGE IN THE ARCTIC AND ANTARCTIC ECOSYSTEMS
}

\section{Summary}

Significant climate change is currently being observed in the Arctic and Antarctic. The increase in average air temperature in the Arctic between 1979 and 2019 tripled that of the global average. In Antarctica, the warming was greatest in the Antarctic Peninsula. Poland is involved in monitoring weather conditions in the Arctic (at the S. Siedlecki station in Hornsund, southern Spitsbergen) and in Antarctica (at the H. Arctowski station on King George Island). Climate change is causing various threats to polar ecosystems, including the melting of glaciers, sea cover, permafrost and snow cover. The species composition of flora and fauna in polar regions is also changing.

Key words: Antarctic, Arctic, climate change, ecosystems 